\title{
PLAYING HIDE AND SEEK: \\ HOW LENDERS RESPOND TO BORROWER PROTECTION
}

\author{
Youssef Benzarti \\ Working Paper 26382 \\ http://www.nber.org/papers/w26382 \\ NATIONAL BUREAU OF ECONOMIC RESEARCH \\ 1050 Massachusetts Avenue \\ Cambridge, MA 02138 \\ October 2019
}

I thank Erik Eyster, Kyle Meng, Ryan Oprea, Heather Royer, Monica Singhal and Alisa Tazhitdinova for helpful comments The views expressed herein are those of the author and do not necessarily reflect the views of the National Bureau of Economic Research.

NBER working papers are circulated for discussion and comment purposes. They have not been peer-reviewed or been subject to the review by the NBER Board of Directors that accompanies official NBER publications.

(C) 2019 by Youssef Benzarti. All rights reserved. Short sections of text, not to exceed two paragraphs, may be quoted without explicit permission provided that full credit, including () notice, is given to the source. 
Playing Hide and Seek: How Lenders Respond to Borrower Protection

Youssef Benzarti

NBER Working Paper No. 26382

October 2019

JEL No. D91,G18,G21,H10

\section{$\underline{\text { ABSTRACT }}$}

This paper uses the universe of mortgage contracts to estimate the response of high-interest lenders to borrower protection regulations aimed at simplifying and making loan terms more transparent. Using a quasi-experimental design, we find that lenders substantially reduce interest rates - by an average of $10 \%$ - in order to avoid being subject to borrower protection, without reducing amounts lent or the number of loans approved. This finding implies that a substantial number of high-interest lenders prefer to issue obfuscatory mortgage contracts with lower interest rates rather than more transparent and regulated mortgages with higher interest rates.

Youssef Benzarti

Department of Economics

University of California

Santa Barbara, CA 93106

and NBER

youssef.benzarti@gmail.com 


\section{Introduction}

Getting a mortgage is one of the most daunting financial transactions people engage in during their lifetime. Mortgages represent a large financial commitment, impose substantial financial risk, and can be extremely complex. Yet, $60 \%$ of US homes currently carry a mortgage. Moreover, housing is the main form of wealth accumulation in the US and given the rise in wealth inequality documented by Saez \& Zucman (2016), access to mortgages for low-wealth households can help reduce the wealth gap. ${ }^{1}$ Because mortgages are so complex and important to US households, the US government has imposed borrower protection clauses aimed at disclosing certain important information and banning certain predatory lending terms. Following the Great Recession, in the past decade, borrower protection in the mortgage market has received renewed attention, leading to the 2010 passage of the Dodd-Frank Act and the 2011 creation of the Consumer Financial Protection Bureau (CFPB).

Nevertheless, such protection is still very controversial. A classic pro-market argument against consumer protection is that predatory lenders offering contracts with shrouded attributes (e.g., hidden fees or high penalties) aimed at taking advantage of consumers should be competed away in well-functioning markets by "transparent lenders." These lenders would educate borrowers on the obfuscating terms that predatory lenders include in their mortgage contracts and steer them away from contracts with shrouded attributes (see Shapiro (1995)). In this case, consumer protection would be unnecessary since market forces would drive away predatory lending. However, Gabaix \& Laibson (2006) question this argument by showing that as long as there are sufficiently many inattentive borrowers and even if markets are perfectly competitive, predatory lenders can survive competition and even thrive. In this case, consumer protection could be desirable since it would prevent predatory lenders from taking advantage of consumer inattention or lack of sophistication.

In this paper, we tackle this question by exploring how lenders respond to regulation aimed at

\footnotetext{
1“U.S. Census Bureau, 2017 American Community Survey 1-Year Estimates" Mortgage Status, Owner-Occupied Housing Units. Accessed August 29th, 2019.
} 
protecting high-interest borrowers. In theory, if none of the lenders are predatory lenders, and if the regulations are not too bureaucratically burdensome, then they should be indifferent to additional regulation aimed at informing consumers and banning hidden fees and high penalties. If instead a substantial portion of lenders take advantage of consumers, they may be willing to bear substantial costs in order to avoid becoming subject to additional borrower protection regulation. Using a quasi-experimental design, we provide evidence consistent with the latter hypothesis.

Our empirical strategy uses the introduction of additional borrower protections triggered by the implementation of the Dodd-Frank Act. In January 2014, the CFPB implemented Dodd-Frank's 2013 Home Ownership and Equity Protection Act (HOEPA) Rule, which applies mainly to highinterest mortgages and imposes additional borrower protections aimed at better informing borrowers of the mortgage terms they are contracting and banning certain hidden fees, penalties and obfuscatory practices. We discuss these new protections in detail in Section 2.2.

These regulations were imposed on loans with interest rate spreads above $6.5 \%$ for loan amounts in excess of $\$ 50,000$, and above $8.5 \%$ for loan amounts smaller than $\$ 50,000$. Interest rate spreads are defined as the difference between the interest rate charged on a loan and the average interest rate charged on a similar loan issued to prime borrowers (borrowers with very good credit histories). We use these interest rate spread thresholds to investigate the response of mortgages to the passage of these regulations. First, we compare the pre- and post-reform distributions of mortgages at and above the two thresholds. This allows us to assess how many of the loans are reclassified from above to below the thresholds. In essence, this is a difference-in-bunching approach, similar to the identification strategy implemented by Best et al. (forthcoming), and is immune to the criticisms of Blomquist \& Newey (2017). Second, we use a more traditional difference-in-differences (DD) approach by comparing outcomes of interest for treated loans and control loans before and after the reform.

The response is stark, as after the regulations' implementation in 2014, we observe a large and rapid decline in the number of mortgages above the thresholds. This decline is compensated by a large increase in the number of mortgages at and just below the thresholds. There is a large excess 
mass in the distribution of mortgages at the thresholds and a substantial missing mass above them. Had this reform resulted in a drop in the supply of mortgages rather than a simple reclassification of mortgages from above to below the thresholds, we would have observed a drop in the total number of mortgages affected by the reform. Instead, we observe that the number of mortgages just below and above the two HOEPA cutoffs is constant pre- and post-reform, implying that the reform, in spite of the reduction in interest rates, has no negative supply effects and instead results in a reduction in interest rates aimed at avoiding the regulation. Moreover, we observe no reduction in average loan amounts. Therefore, the total supply of credit is not reduced via this intensive margin either.

The consequence of both the extensive and intensive margins being unaffected is that the borrower protections do not appear to reduce the total supply of credit. Instead mortgages are being reclassified into lower-interest loans which are not subject to the additional transparency requirements. As a consequence, the average interest rate per loan for these high-interest mortgages decreases by a little more than $10 \%(\simeq 1$ percentage point of interest). Since African American, Hispanic, and low-income borrowers are over-represented within the population of high-interest borrowers, these three demographic groups are more affected by this interest rate reduction.

Four points are worth emphasizing regarding our interpretation of these results. First, in theory, the response we estimate could be driven by borrowers rather than lenders. As borrowers receive more information about mortgage contracts, they decide to contract lower-interest mortgages. However, this explanation is unlikely because it would not result in bunching at the cutoffs: there is no reason for better-informed borrowers to demand mortgage contracts with interest rates just below the cutoffs. Instead, this seems more consistent with lenders reducing interest rates just enough so as to avoid the HOEPA flag.

A second possible but unlikely interpretation of our results is that lenders are reducing their APR below the cutoffs not to avoid borrower protections per se but to avoid the bureaucratic cost of implementing the new HOEPA regulations. This is unlikely because all lenders, irrespective of whether they issue HOEPA loans or not, are now subject to this bureaucratic cost. According 
to the CFPB guide to complying with the 2013 HOEPA Rule intended for banks: "Even if your organization does not originate high-cost loans, you will need to update your systems and processes which execute the HOEPA coverage tests to ensure compliance with the criteria as defined in this rule." 2 Therefore reducing APRs below the thresholds would not mitigate the costs of complying with the new HOEPA regulation. ${ }^{3}$

Third, one may argue that the response we estimate is due to lenders misreporting the interest they actually charge to borrowers to avoid being subject to HOEPA regulations. This is unlikely for several reasons: (1) banks can face criminal charges if they forge documents related to mortgage contracts, and (2) this data is routinely audited by the CFPB, which ensures that the reported information corresponds to the actual contract issued, and given that the CFPB implemented the regulation, one can reasonably expect that they would audit banks that bunch below the threshold to ensure that they are not avoiding the regulation by misreporting. Overall, the expected cost of misreporting APRs is likely to greatly exceed the forgone profits of simply charging lower APRs. However, even if banks were engaging in fraudulent misreporting, this would even further reinforce the message of this paper, which is that lenders go to great lengths in order to avoid borrower protection clauses.

Fourth and last, note that in our dataset we do not observe all the terms of a given mortgage contract, in particular we do not observe hidden fees or penalties. This means that, in principle, lenders could be redesigning their contracts by decreasing interest rates and compensating for this loss by creating new fees or penalties, which would be consistent with the model of Heidhues et al. (2016a). This is possible and further reinforces the idea that banks profit from hidden prices more than from APRs. And while, in principle, the 2013 HOEPA regulation seems to increase welfare via a decrease in interest rates, it might not be the case if lenders are increasing hidden fees and penalties to compensate for the decrease in interest rates.

Our findings are important for the following reasons: First, ensuring that borrowers are fully

\footnotetext{
${ }^{2}$ See Section 6 (page 30) of the guide, which can be found here: link.

${ }^{3}$ In addition, given that high-interest borrowers are likely to be very inelastic, a standard incidence model would predict that any cost increase would be passed through to the APR, while instead we estimate a decrease in APRs.
} 
informed about the contracts they sign when committing to a mortgage is of imminent policy relevance. Presumably, borrowers signing contracts they did not really understand is part of what led to the subprime mortgage expansion and then collapse and later to the Great Recession. Designing regulation that can better inform borrowers and shape simpler and more transparent mortgage contracts could help avert a repeat of this situation.

Second, while the number of borrowers we consider is relatively small compared to the total number of borrowers in the US, the population we focus on is an at-risk population of particular policy interest. High-interest mortgages are more likely to be contracted by low-income individuals and minorities, who are also at a higher risk of being financially constrained and more prone to be the target of predatory lending practices. On average, African Americans are 2.2 times and Hispanics 1.6 times more likely to contract these mortgages. ${ }^{4}$ In addition, these mortgages mostly attract low-income borrowers: the average income of high-interest borrowers is half that of nonhigh-interest borrowers.

Third, all of the contracts we consider are for the purchase of a primary dwelling, and defaulting on these mortgages can have serious consequences for families in the above-mentioned populations. At the same time, high-interest borrowers are also the ones who are the most likely to benefit from additional credit since they are the most likely to be credit constrained. As Saez \& Zucman (2016) have documented, low-income individuals are accumulating relatively less and less wealth. And since housing is the main vehicle of wealth accumulation in the US, where housing wealth constitutes almost two-thirds of the median household's total wealth (Iacoviello (2011)), having safe access to mortgages can help reduce the wealth gap.

Fourth and last, with the rise in behavioral economics and the recognition that individuals do not always act in their own best interest, there has been interest in designing and implementing soft interventions aimed at nudging individuals toward the "right" choice. One such intervention is requiring firms to disclose additional information in an intelligible and informative way. Our findings can inform policy makers as to how lenders respond to such interventions.

\footnotetext{
${ }^{4}$ See Table 1.
} 
While our paper is the first to analyze the supply response of mortgage lenders to borrower protection, it is related to three main literatures. First, our paper is related to a theoretical literature in behavioral economics analyzing the market effects of hidden prices. ${ }^{5}$ While the consensus was that hidden prices and shrouded attributes should disappear in a perfectly competitive market, Gabaix \& Laibson (2006) challenged this idea by showing that if enough consumers underweight hidden prices firms will not educate them and shrouded attributes and hidden prices will persist. This underweighting of hidden prices could be driven by several biases, including a focusing and salience bias as shown in Bordalo et al. (2012) and Kőszegi \& Szeidl (2012). It could also be due to a form of time inconsistency: Heidhues \& Kőszegi (2010) show that some consumers' preference for immediate gratification can lead lenders to issue predatory loans aimed at taking advantage of this preference. Our paper offers a test and supporting evidence of these theories by estimating the response of firms to regulations where they are given the choice of either abiding by the added borrower protections or avoiding them by cutting interest rates. We find that firms predominantly avoid these regulations, resulting in large interest rate cuts, which is consistent with lenders profiting from hidden prices.

Second, our paper contributes to a literature that analyzes regulations in credit markets, which has mostly focused on consumer credit and predatory lending. Agarwal et al. (2014), for example, compellingly show that when credit card fees were capped, as a consequence of the CARD Act, consumers ended up saving substantial amounts of money because banks did not compensate for the loss of fees by increasing interest rates or reducing the supply of credit. Our paper is also related to the literature analyzing payday loans which are usually targeted at low-income individuals (see, for example, Skiba \& Tobacman (2008)). Our paper contributes to this literature in two ways: (1) by focusing on the response of lenders to borrower protection regulations and its implication regarding how much they value hidden prices, and (2) by considering another market of imminent policy relevance where consumer protections can have important implications.

\footnotetext{
${ }^{5}$ More generally, our paper is related to a literature in behavioral economics that explores how firms take advantage of mistakes in consumer decisions (see DellaVigna \& Malmendier (2006), Eliaz \& Spiegler (2006), Grubb (2009), Heidhues \& Kőszegi (2008), Heidhues et al. (2016b), Heidhues \& Köszegi (2017), Heidhues et al. (2016a), Murooka (2013).)
} 
Third, our paper is also related to an empirical literature exploring the effects of disclosure and simplification on consumer behavior. Allcott \& Taubinsky (2015), for example, estimate the demand effect of informing consumers on the savings they can derive from buying more energyefficient lightbulbs. Duarte \& Hastings (2012) provide compelling empirical evidence that in the Mexican market for retirement financing, where regulations to simplify disclosure can prompt fund managers to game the system by offering more expensive funds that appear cheaper because of the simplified disclosure, investors choose a dominated investment option.

\section{Data and Institutional Setting}

\subsection{Data}

We use the Home Mortgage Disclosure Act (HMDA) data, which is an annual registry of all US mortgage applications and approval decisions dating back to $1980 .{ }^{6}$ The dataset contains detailed information on mortgage contracts, including their date of issuance, the branch and bank issuing them, the interest rate spread (defined below), the amount sought, and whether the loan is approved and if not what reasons caused the loan application to be denied. ${ }^{7}$ The dataset also contains detailed demographics on the borrower, including race, ethnicity, gender, and income, and the zip code where the dwelling is being purchased.

The variation we use in this paper is based on the interest rate spread of a given mortgage, which is defined as the difference between the APR (annual percentage rate) of the mortgage and the average APR on prime mortgages (mortgages issued to borrowers with very good credit histories) of a comparable type offered when the mortgage application is submitted. ${ }^{8}$ Note that the

\footnotetext{
${ }^{6}$ This dataset can be freely downloaded from the Consumer Financial Protection Bureau's website: https://www. consumerfinance.gov/data-research/hmda/

${ }^{7}$ Only approved loans are included in the dataset for loans subject to HOEPA regulations.

${ }^{8}$ To ensure that mortgages are of comparable types, the CFPB differentiates between fixed versus variable mortgages, type of amortization, lock-in date, fixed term versus variable term, and reverse mortgages. For example, if the average APR for all fixed interest mortgages with a lock-in date of February 1, 2016, with fixed amortization and a 30 -year term is $5 \%$ and a borrower applies for a loan that matches these characteristics on February 1, 2016 and is offered an APR of $9 \%$ then the interest rate spread reported in the dataset is $4 \%$.
} 
interest rate spread is directly reported in the HMDA dataset and that the only way a lender can adjust the interest rate spread in order to target the $6.5 \%$ and $8.5 \%$ cutoffs is to change the interest rate itself. Note also that the HMDA dataset only contains information on interest rate spreads in excess of $1.5 \%$. This censoring does not affect our results since our variation affects loans that are far in excess of this threshold $(6.5 \%$ and $8.5 \%)$. Finally, the only data restriction we make is that we only consider loans that are approved and discard any loan applications that are denied or eventually withdrawn.

Table 1 provides some summary statistics and compares high- versus low-interest borrowers. High-interest borrowers earn substantially less than low-interest borrowers - 50\% less, on average, and are also much more likely to be African American, Hispanic, and female. While it is true that they only represent a small portion of the total mortgage market, high-interest borrowers are of particular interest because they represent a high-risk population.

\subsection{Institutional Setting}

On January 31, 2013, in implementing the 2010 Dodd-Frank Act, the CFPB issued the 2013 HOEPA Rule, which affected high-interest home purchase loans. ${ }^{9}$ The new rule was implemented on January 10, 2014. Under this rule, a home purchase loan is subject to additional borrower protection clauses (detailed below) if this loan satisfies at least one of the following conditions:

1. The interest rate spread exceeds $6.5 \%$ for loan amounts in excess of or equal to $\$ 50,000$.

2. The interest rate spread exceeds $8.5 \%$ for loan amounts smaller than $\$ 50,000$.

3. The loan has fees and points exceeding one of these two thresholds:

- $5 \%$ of the total loan amount for loan amounts greater than or equal to $\$ 20,000$, or

- $8 \%$ of the total loan amount or $\$ 1,000$ (whichever is less) for a loan amount less than $\$ 20,000$.

4. The loan has prepayment penalties that exceed $2 \%$ of the amount prepaid.

\footnotetext{
${ }^{9}$ The Home Ownership and Equity Protection Act was first enacted in 1994, but only covered refinance and home equity loans.
} 
In this paper, we focus on the variation triggered by the $6.5 \%$ and $8.5 \%$ interest rate spread thresholds. We cannot estimate the effect of the thresholds based on points, fees and penalties because we do not observe them in our dataset. If loans are subject to HOEPA coverage then they must abide by the following four categories of borrower protection clauses:

1. Disclose the following: (1) inform the borrower that the loan will not be effective until the account is open, (2) explain the consequences of default, and (3) disclose the loan terms (APR, amount borrowed, and monthly payment).

2. Applicants are required to meet with a counselor approved by the Housing and Urban Development Agency (HUD) before the loan can be approved. The counseling fee can be paid by the lender or the borrower (either up front or financed by the loan). Note that the counselor cannot be affiliated with or employed by the lender.

3. The following loan terms are banned: (1) balloon payments, which require, in addition to the regular monthly payments, one larger payment (generally more than double the monthly payments) at the end of the loan; and (2) due-on-demand features, which allow the lender to require immediate repayment of the entirety of the loan without requiring a reason.

4. In addition, these loans are subject to the following restrictions on points and fees: (1) fees to modify a mortgage contract are banned, (2) late fees are capped to $4 \%$ and cannot be pyramided, (3) fees for generating payoff statements, which are statements that show the remaining balance needed to close the loan, are banned, and (4) points and fees cannot be financed by the loan being approved. ${ }^{10}$

All of these conditions are aimed at limiting hidden fees and at ensuring that borrowers are informed of the features of the loan they are contracting. Note that lenders are explicitly forbidden from restructuring a loan to avoid the HOEPA regulations - by splitting a loan into two, for example.

\footnotetext{
${ }^{10}$ Points are fees paid to the lender in order to reduce the interest rate. Fee pyramiding describes the following practice: a homeowner (1) misses the deadline for a payment; (2) is charged a late fee; (3) makes all monthly payments on time after that one month of being late, but does not pay the late fee; and (4) the mortgage company keeps charging a late fee on all the payments made on time.
} 


\section{Identification Strategy}

We implement two different identification strategies. First, we use a difference-in-bunching strategy similar to Best et al. (forthcoming), which allows us to estimate how the supply of mortgages responds to the $6.5 \%$ and $8.5 \%$ HOEPA cutoffs, and in particular whether after implementation of the rule lenders continue to issue the types of loans it covers in the same number as before. Second, we use a standard DD strategy to estimate the response of different outcomes of interest to the reform. In the following section, we explain how we implement each of them.

\subsection{Difference-in-Bunching Approach}

We compare the distribution of interest rate spread around the two thresholds we use for identification before and after the reform. The standard bunching approach, as implemented in Saez (2010), Chetty et al. (2011), and Kleven \& Waseem (2013), assumes that distributions are generally smooth, and if there is excess mass at a policy threshold, it must be due to behavioral responses to the policy. One can then use a smoothed distribution as a counterfactual to estimate the size of the excess mass and the corresponding behavioral response. The difference-in-bunching approach, implemented in Best et al. (forthcoming) and used in this paper, relaxes the smoothness assumption and uses the pre-reform distributions as a counterfactual instead of the smoothed distribution. This approach has the advantage of requiring fewer assumptions on the counterfactual distribution and is robust to the criticisms of Blomquist \& Newey (2017). It is similar in spirit to a DD strategy whereby the pre-reform difference in densities just above and just below the threshold are compared to the same difference post reform. Practically, we compare the difference in density in a given bin before and after the reform. The main identification assumption is that the distributions would have looked similar before and after 2014 had there been no change in 2014. Similarly to a DD identification strategy, this can be checked by ensuring that the pre-reform distributions are similar. We implement this test and discuss it in Section 4. Formally we estimate the following difference: 


$$
\hat{c}_{i}=c_{i}^{\text {post }}-c_{i}^{\text {pre }}
$$

where $c_{i}^{\text {post }}$ is the number of mortgages in bin $i$ after the 2014 change, $c_{i}^{\text {pre }}$ the number of mortgages in bin $i$ before the 2014 change and $\hat{c}_{i}$ the difference between the two and we use bootstrap to get the standard errors of the difference. This approach allows us to estimate the change in the number of mortgages per bin of interest rate spread before and after the introduction of the $6.5 \%$ and $8.5 \%$ interest spread thresholds. Note that we define the start of the bunching (excess mass) area as as the first bin $i$ such that $\hat{c}_{i}$ is statistically significantly different from zero at the $5 \%$ level and denote it by $\underline{\mathrm{c}}$.

In principle, we could also implement the standard bunching approach, but our approach has the advantage of not requiring assumptions over the shape of the counterfactual distribution, since the pre-reform distribution can be used as a counterfactual.

\subsection{Difference-in-Differences Approach}

In order to estimate the effect of the reform on average loan outcomes, we compare the difference in loans above and below the thresholds before and after the reform. Formally, we implement the following specification:

$$
Y_{i, t}=\alpha_{0}+\alpha_{1} \text { Above }_{i}+\alpha_{2} \text { Post }_{t}+\alpha_{3}\left(\text { Above }_{i} * \text { Post }_{t}\right)+\varepsilon_{i, t},
$$

where $Y$ is the outcome variable of interest for a given loan $i$, and $t$ is years. Above is a dummy variable equal to 1 for loans with interest rate spreads greater or equal to $\underline{\mathrm{c}}$ (as defined above), and equal to 0 otherwise. Post refers to the period after the reform (from 2014 onward). We cluster standard errors at the lender level.

The main identification assumption for this approach is that absent the reform, outcomes would have evolved in a similar pattern. A common test of this assumption is to ensure that the trends are parallel prior to the reform. We implement this test and discuss it in Section 4.

For mortgages with loan amounts in excess of $\$ 50,000$, the area where bunching start, i.e., $\underline{\mathrm{c}}$ is 
equal to $5.75 \%$ and for loan amounts less than $\$ 50,000$, it is equal to $7.75 \%$, as shown in Figures 2 and 3.

\section{Results}

Response to the Thresholds Figure 1 shows the distributions of loans by bin of interest rate spread around the $6.5 \%$ and $8.5 \%$ HOEPA thresholds. ${ }^{11}$ Notice that there is no excess mass at $6.5 \%$ and $8.5 \%$ in years 2010 to 2013 , when the two HOEPA thresholds did not exist, as shown in Figures 1a and 1b. As the thresholds are introduced in 2014, an excess mass appears just below the $6.5 \%$ and $8.5 \%$ thresholds and grows bigger in later years, as shown in Figures 1c and 1d. The response is large, affecting loans with interest rate spreads above the cutoffs, implying that lenders prefer cutting interest rates by several percentage points rather than being subject to additional borrower protections.

These figures provide non-parametric evidence of the fact that lenders respond to the policy discontinuity by decreasing the number of loans above the thresholds and increasing them just below the thresholds. Figures 2 and 3 plot the difference between the 2013 and 2014, 2015, 2016, and 2017 distributions for the $6.5 \%$ and $8.5 \%$ cutoffs, respectively, with the corresponding $95 \%$ confidence intervals based on bootstrapped standard errors. The figures shows that the differences close to the cutoffs are statistically significantly different from zero.

Figure 4 shows the pre- and post-reform number of loans just below and above the thresholds. This figure shows that the bins that are 1.5 to 1 interest points below the threshold are not affected by the reform, whereas the ones that are less than 1 point below the threshold experience a large increase immediately after the threshold is introduced at the expense of loans that are above the thresholds, which decrease discontinuously in 2014. In addition, this figure shows that the overall supply of loans is not substantially negatively affected by the reform. This is important because many of the arguments against borrower protection assert that such regulations will end up hurt-

\footnotetext{
${ }^{11}$ Appendix Figures A.1, A.2, A.3 and A.4 show the distributions for years 2010 to 2017 separately for each year and for mortgages with amounts lent above and below the $\$ 50,000$ cutoff.
} 
ing consumers by cutting the supply of loans, an effect that does not appear to be at play here, undermining such arguments.

In principle, the total credit issued could also be affected by a decrease in the loan amounts via an intensive margin response - by decreasing amounts lent per loan. However, Figure A.6 shows that the total credit issued for loans in the neighborhood of the HOEPA threshold has not substantially changed at the time of the reform. For loan amounts in excess of $\$ 50,000$, total credit levels for loans just below and above the threshold respond to the reform similarly to loans that are away from the threshold, as shown in Appendix Figure A.6a, suggesting that there was no substantial response of total credit to the reform. We observe similar patterns for loan amounts smaller than $\$ 50,000$ in Appendix Figure A.6b, with the caveat that the $\$ 50,000$ threshold artificially limits credit growth for these loans.

As the number of loans below the threshold increases below and decreases above the threshold, average interest rates should decrease. Figure 5 plots the average interest rate for loans just below and above the threshold. The figure shows a decrease in interest rates, which is confirmed in Table 2, which shows the result of estimating equation (2) on interest rates. We estimate a 0.6 percentage point decrease (loans greater than $\$ 50,000$ ) and 0.93 percentage point decrease (loans smaller than $\$ 50,000)$ in average interest rates for loans issued just below and above the cutoffs. This implies substantial savings for borrowers. Given that the average loan amount is $\$ 80,000$ for loans in excess of $\$ 50,000$ and $\$ 29,000$ for loans smaller than $\$ 50,000$, and assuming a loan term of 30 years, this amounts to interest payment savings over the entire loan of $\$ 21,000$ for the former and $\$ 8,236$ for the latter. Given the size of the population affected by these loans, the aggregate interest savings amount to approximately $\$ 500$ million for a majority low-income population.

Overall, this implies that the reform resulted in a decrease in average interest rates, with no substantial negative supply effects. Assuming that the goal of this policy was to provide additional borrower protection rather than decrease interest rates, these effects appear to be unintended consequences of the policy intervention. Rather than offering additional borrower protections, lenders are avoiding them by forgoing profits from interest rates, which would imply that the profits they 
derive from hidden prices are likely high.

Entry and Exit of Lenders Presumably, if the high-interest mortgage market is competitive and lenders are forced to decrease interest rates, we should observe some lenders exiting the market. If instead, lenders are charging substantial markups on interest rates, they would be able to withstand a decrease in interest rates.

Testing for whether lenders exit the high-interest mortgage market is not straightforward because banks do not tend to specialize in high-interest loans. Figure 6a shows the proportion of high-interest loans as a percentage of total loans issued by banks. While there is an excess mass at zero, implying that some banks never issue high-interest mortgages, there is no spike around 1, implying that no banks specialize in high-interest mortgages. Figures $6 \mathrm{~b}$ and $6 \mathrm{c}$ show the distribution of high-interest loans as a percentage of total loans issued by a given bank before and after the HOEPA threshold is introduced. These figures show that the proportion of high-interest loans in a given bank's portfolio of loans decreases sharply after the HOEPA threshold is introduced. Figures $7 \mathrm{a}$ and $7 \mathrm{~b}$, which compare the number of banks issuing loans above the HOEPA thresholds to just below them, show that the number of lenders issuing loans above the cutoffs drops discontinuously when the cutoffs are introduced, which could be consistent with these lenders exiting the lending market altogether or simply not issuing anymore loans above the interest rate spread cutoffs.

\section{Implications and Alternative Explanations}

\subsection{Implications}

Lenders are averse to borrower protections. As shown in Figure 5, lenders actively reduce interest rates in order to approve mortgages that are just below the HOEPA coverage cutoff. This implies that they are willing to trade off profits from higher interest rates in exchange for laxer borrower protections. This is a revealed-preference argument that lenders value lax borrower protections possibly because it makes it easier for them to profit from borrowers' inattention to hidden 
fees, penalties, and shrouded attributes in general. This also suggests, at least for high-interest loans, that a non-trivial portion of lenders' profits are generated by fees and penalties rather than the interest rates they charge.

Borrower protection does not appear to reduce the supply of high-interest loans. Since average loan amounts and the number of loans approved do not decrease following the introduction of the $6.5 \%$ and $8.5 \%$ HOEPA thresholds, as shown in Figure 4, we can reasonably claim that this type of protection does not reduce the supply of high-interest loans. This is particularly important because critics of consumer protections argue that they can end up harming consumers by imposing additional burdens on suppliers which can lead them reduce the total supply of credit, which does not appear to be the case here.

Are borrowers better off after the reform? After the reform, borrowers receive lower interest rates - on average 0.6 to 0.9 percentage points lower - and do not suffer any meaningful credit supply cuts. Therefore, ceteris paribus, they should be better off. However, it is possible that lenders compensate for the decrease in interest rates with higher hidden fees and penalties, as long as they do not exceed certain thresholds set by the 2013 HOEPA Rule as that would trigger HOEPA coverage (see Section 2.2). Therefore, the welfare implications of the reform for consumers is ambiguous: on the one had they benefit from lower interest rates, but on the other hand they could be paying higher fees and penalties.

\subsection{Alternative Explanations}

Administrative costs. The main alternative explanation to lenders avoiding borrower protections because they want to keep charging hidden fees and using hidden prices is that they want to avoid the regulations because they impose administrative costs on them. If the administrative costs of offering loans subject to HOEPA coverage exceed the profits lenders realize from being able to charge higher interest rates, it is conceivable that some lenders will reduce interest rates in order to 
avoid these costs.

This explanation is unlikely for two reasons. First, if borrowers are less elastic than lenders, which is likely to be the case for high-interest loans, a simple incidence model would predict that the additional administrative costs of HOEPA regulations would be passed through to borrowers via an increase in interest rates, instead we observe a decrease in interest rates. Second, and more important, all lenders, irrespective of whether they issue loans subject to HOEPA coverage or not, are now subject to the administrative costs of complying with the HOEPA regulations. This is clearly stated in the guidelines issued by CFPB to lenders and can found on Section 6 (page 30) of the guide. ${ }^{12}$

Misreporting. Could lenders be fraudulently misreporting interest rates in order to avoid HOEPA coverage? While we do not have evidence in support of or against this, it seems reasonably unlikely that lenders would engage in such behavior for the following reasons: (1) banks can face criminal charges if they forge documents related to mortgage contracts, and (2) this data is routinely audited by the CFPB, which ensures that the information reported corresponds to the actual contract issued, and given that the CFPB implemented the regulation, one can reasonably expect that they would audit banks that bunch below the threshold. Overall, the expected cost of misreporting APRs is likely to greatly exceed the profits forgone by simply charging lower APRs, especially given that there are very few banks that specialize in HOEPA loans exclusively (as shown in Figure 6a). However, even if banks were to engage in fraudulent misreporting, this would even further reinforce the message of this paper, which is that lenders can go to great lengths - in this case, committing perjury and facing criminal charges - in order to avoid implementing borrower protection clauses.

Demand response. Part of the goal of the 2013 HOEPA regulations is to inform borrowers who contract loans above the two cutoffs of the loan terms. Could it be that once borrowers are better informed, they request lower interest rates? While possible in principle, the evidence from Figure 1 does not seem to fit this explanation well. In particular, if this is the case, it is unclear why

\footnotetext{
${ }^{12}$ The guide can be found here: link.
} 
newly informed borrowers would request loans that are exactly at the threshold. A more plausible demand-driven explanation is that once informed, borrowers would request lower fees and penalties but not necessarily lower APRs, since fees and penalties are made more salient by the 2013 HOEPA regulation, whereas APRs were always disclosed both before and after the reform.

\section{Conclusion}

Consumer protection is controversial. On the one hand, advocates of "laissez-faire" believe that, as long as markets function properly, consumer protection is unnecessary because predatory firms are likely to be competed away by honest firms that would help educate and inform consumers. On the other hand, advances in behavioral economics suggest otherwise: if consumers are inattentive, predatory firms can thrive. In this paper, we show that lenders are willing to forgo profits from higher interest rates in order to avoid consumer protection, which we argue is consistent with the latter hypothesis.

Given the risks mortgages impose on borrowers and on the economy in general, and their important role in wealth accumulation, our findings imply that borrower protection in the highinterest mortgage market may be warranted, since markets are not able to ensure that consumers are protected from hidden fees and obfuscatory practices.

\section{References}

Agarwal, Sumit, Souphala Chomsisengphet, Neale Mahoney \& Johannes Stroebel. 2014. Regulating Consumer Financial Products: Evidence From Credit Cards. The Quarterly Journal of Economics 130(1). 111-164.

Allcott, Hunt \& Dmitry Taubinsky. 2015. Evaluating Behaviorally Motivated Policy: Experimental Evidence From The Lightbulb Market. American Economic Review 105(8). 2501-38.

Best, Michael Carlos, James Cloyne, Ethan Ilzetzki \& Henrik Kleven. forthcoming. Estimating The Elasticity Of Intertemporal Substitution Using Mortgage Notches. The Review of Economic Studies, forthcoming.

Blomquist, Sören \& Whitney Newey. 2017. The Bunching Estimator Cannot Identify The Taxable Income Elasticity. Working paper National Bureau of Economic Research.

Bordalo, Pedro, Nicola Gennaioli \& Andrei Shleifer. 2012. Salience Theory Of Choice Under Risk. The Quarterly Journal of Economics 127(3). 1243-1285. 
Chetty, Raj, John N Friedman, Tore Olsen \& Luigi Pistaferri. 2011. Adjustment Costs, Firm Responses, and Micro vs. Macro Labor Supply Elasticities: Evidence From Danish Tax Records. The Quarterly Journal ff Economics 126(2). 749-804.

DellaVigna, Stefano \& Ulrike Malmendier. 2006. Paying Not To Go To The Gym. american economic Review 96(3). 694-719.

Duarte, Fabian \& Justine S Hastings. 2012. Fettered Consumers And Sophisticated Firms: Evidence From Mexico's Privatized Social Security Market. Working paper National Bureau of Economic Research.

Eliaz, Kfir \& Ran Spiegler. 2006. Contracting with Diversely Naive Agents. The Review of Economic Studies 73(3). 689-714.

Gabaix, Xavier \& David Laibson. 2006. Shrouded Attributes, Consumer Myopia, And Information Suppression In Competitive Markets. The Quarterly Journal of Economics 121(2). 505-540.

Grubb, Michael D. 2009. Selling to Overconfident Consumers. American Economic Review 99(5). 1770-1807.

Heidhues, Paul \& Botond Kőszegi. 2008. Competition and Price Variation When Consumers Are Loss Averse. American Economic Review 98(4). 1245-68.

Heidhues, Paul \& Botond Kőszegi. 2010. Exploiting Naivete About Self-Control In the Credit Market. American Economic Review 100(5). 2279-2303.

Heidhues, Paul \& Botond Kőszegi. 2017. Naivete-Based Discrimination. The Quarterly Journal of Economics 132(2). 1019-1054.

Heidhues, Paul, Botond Kőszegi \& Takeshi Murooka. 2016a. Exploitative Innovation. American Economic Journal: Microeconomics 8(1). 1-23.

Heidhues, Paul, Botond Kőszegi \& Takeshi Murooka. 2016b. Inferior Products and Profitable Deception. The Review of Economic Studies 84(1). 323-356.

Iacoviello, Matteo M. 2011. Housing Wealth and Consumption. FRB International Finance Discussion Paper (1027).

Kleven, Henrik J \& Mazhar Waseem. 2013. Using Notches to Uncover Optimization Frictions and Structural Elasticities: Theory and Evidence From Pakistan. The Quarterly Journal of Economics 128(2). 669-723.

Kőszegi, Botond \& Adam Szeidl. 2012. A Model of Focusing in Economic Choice. The Quarterly Journal of Economics 128(1). 53-104.

Murooka, Takeshi. 2013. Deception Under Competitive Intermediation. Working paper.

Saez, Emmanuel. 2010. Do Taxpayers Bunch at Kink Points? American economic Journal: economic policy 2(3). 180-212.

Saez, Emmanuel \& Gabriel Zucman. 2016. Wealth Inequality In the United States Since 1913: Evidence from Capitalized Income Tax Data. The Quarterly Journal of Economics 131(2). 519_ 578.

Shapiro, Carl. 1995. Aftermarkets and Consumer Welfare: Making Sense of Kodak. Antitrust Law Journal 63(2). 483-511.

Skiba, Paige Marta \& Jeremy Tobacman. 2008. Payday Loans, Uncertainty and Discounting: Explaining Patterns of Borrowing, Repayment, And Default. Vanderbilt Law and Economics Research Paper (08-33). 
Figure 1: Pre- and Post-Reform Distributions of Loans By Interest Rate Spread

(a) Years 2010 to 2013: Loan Amounts $>\$ 50,000$

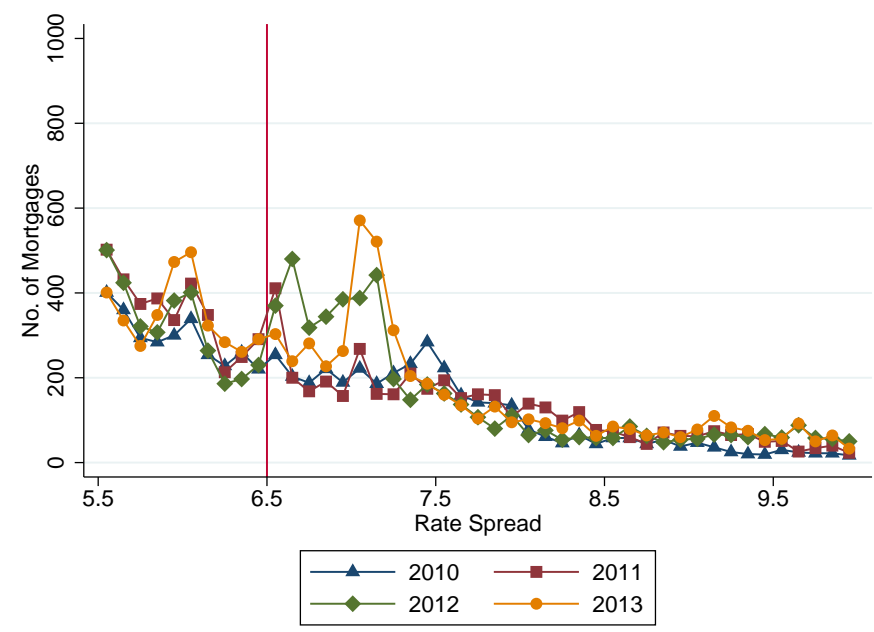

(c) Years 2013 to 2017: Loan Amounts $\geq \$ 50,000$ :

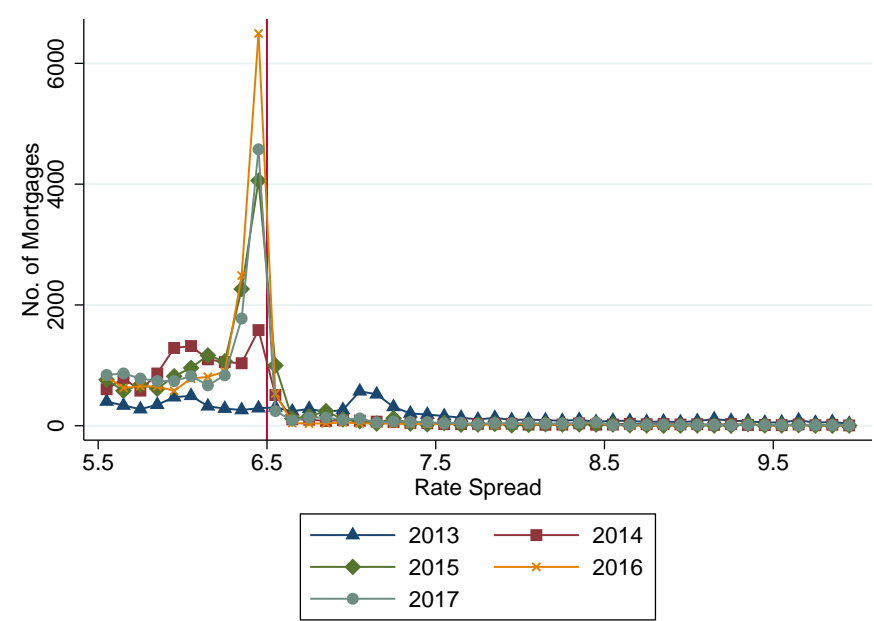

(b) Years 2010 to 2013: Loan Amounts $<\$ 50,000$

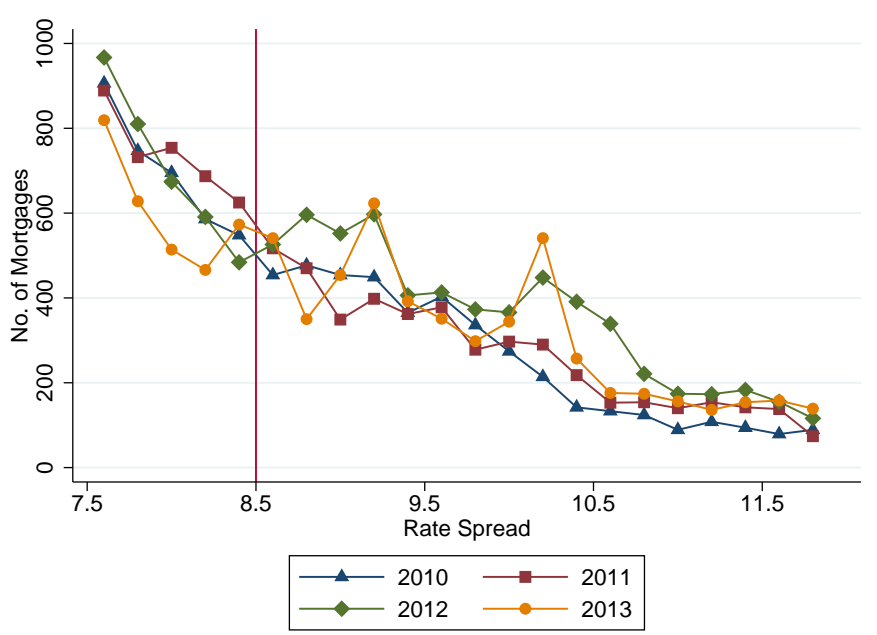

(d) Years 2013 to 2017: Loan Amounts < \$50,000:

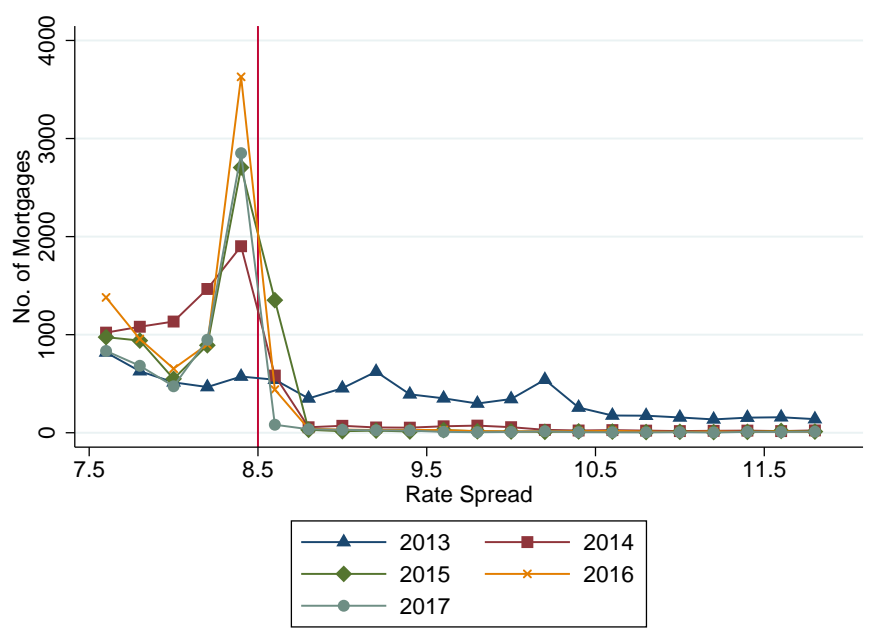

Notes: These figures plot the distribution of mortgages by interest rate spread before and after the 2014 introduction of the HOEPA cutoffs. The vertical red line represents the $6.5 \%$ and $8.5 \%$ HOEPA cutoffs. The bin size is 0.1 for mortgages with loan amounts $\geq \$ 50,000$ and 0.2 for mortgages with loan amounts $<\$ 50,000$. 
Figure 2: Difference in Pre- and Post-Reform Distributions: Loan Amounts $\geq \$ 50,000$

(a) 2014-2013

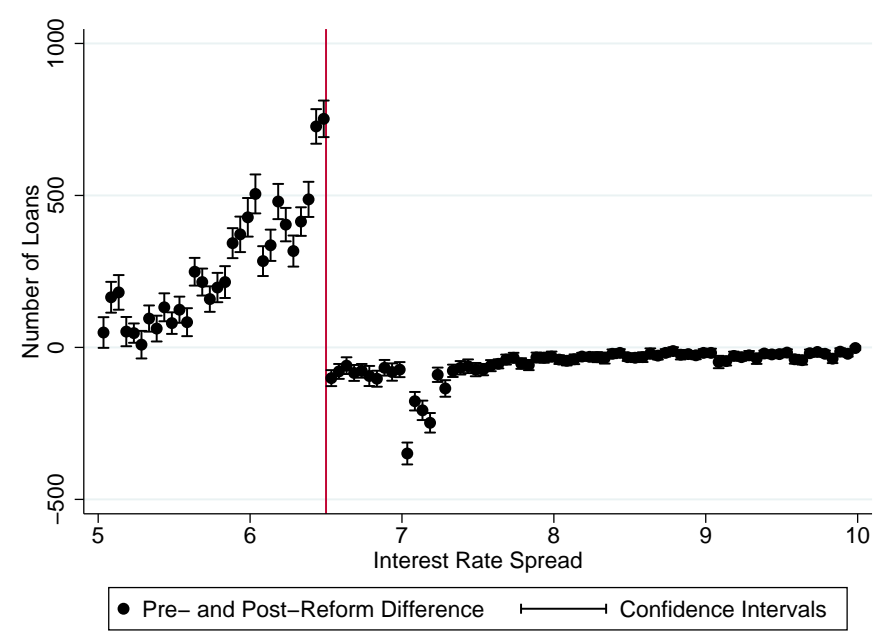

(c) 2016-2013

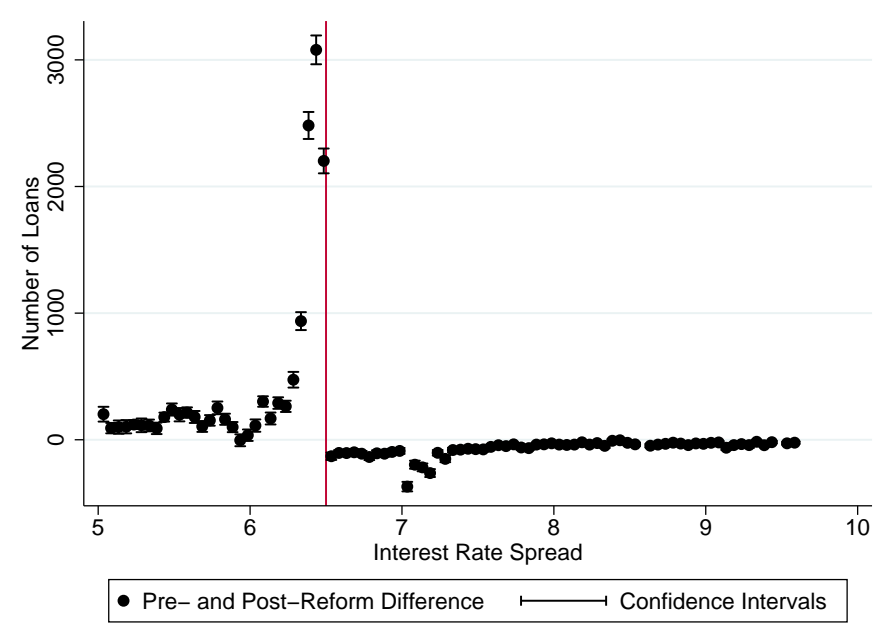

(b) 2015-2013

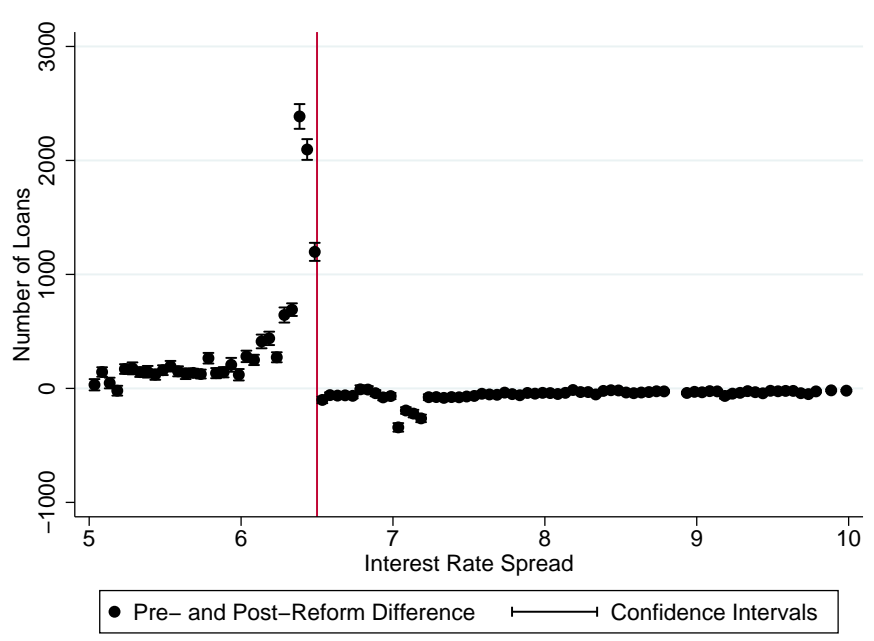

(d) $2017-2013$

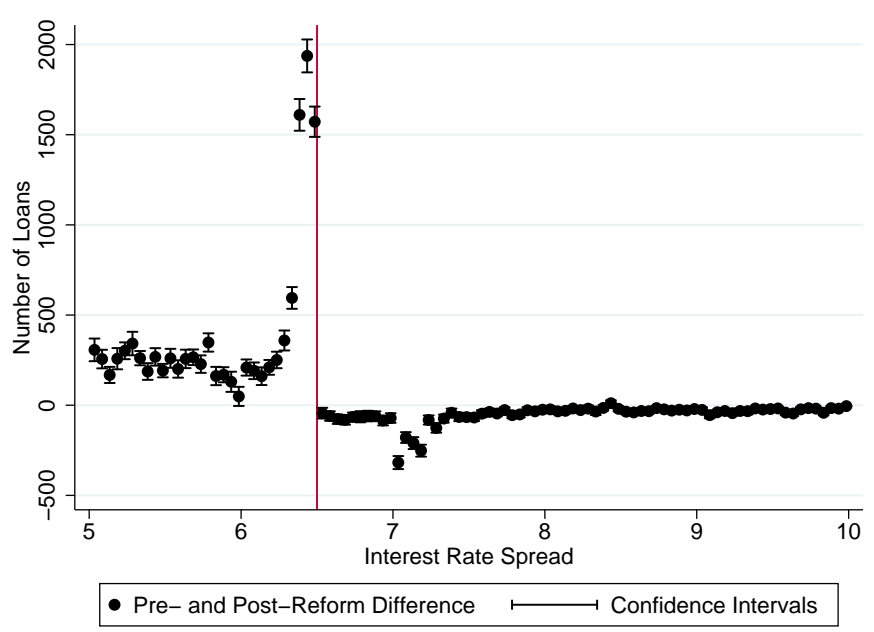

Notes: These figures plot the difference in the pre- and post-reform distributions around the 6.5\% HOEPA cutoff, comparing 2013 to 2014 (Figure 2a), 2015 (Figure 2b), 2016 (Figure 2c) and 2017 (Figure 2d). The red vertical line represents the 6.5\% cutoff and the bin size is 0.05 . The bars represent the $95 \%$ confidence intervals. 
Figure 3: Difference in Pre- and Post-Reform Distributions: Loan Amounts $<\$ 50,000$

(a) 2014-2013

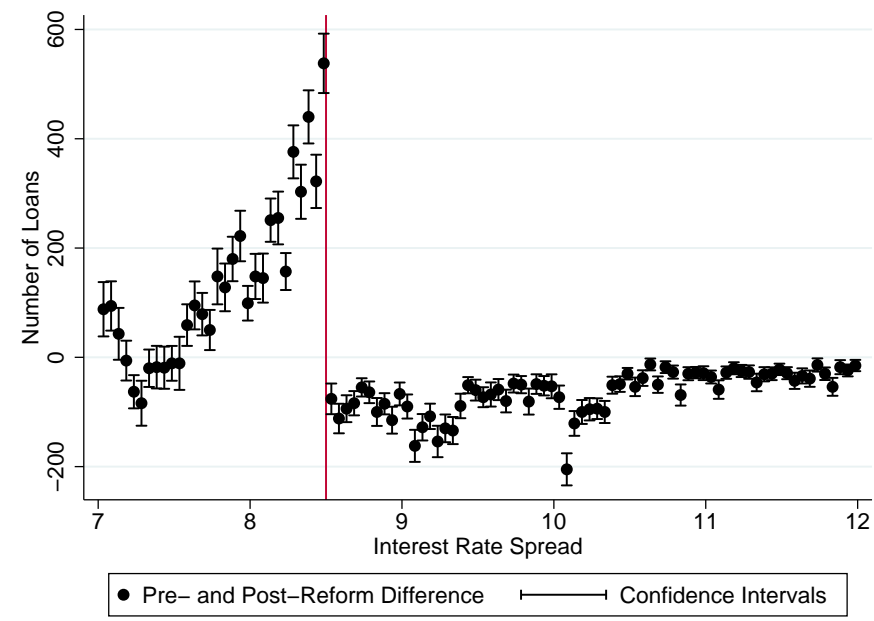

(c) $2016-2013$

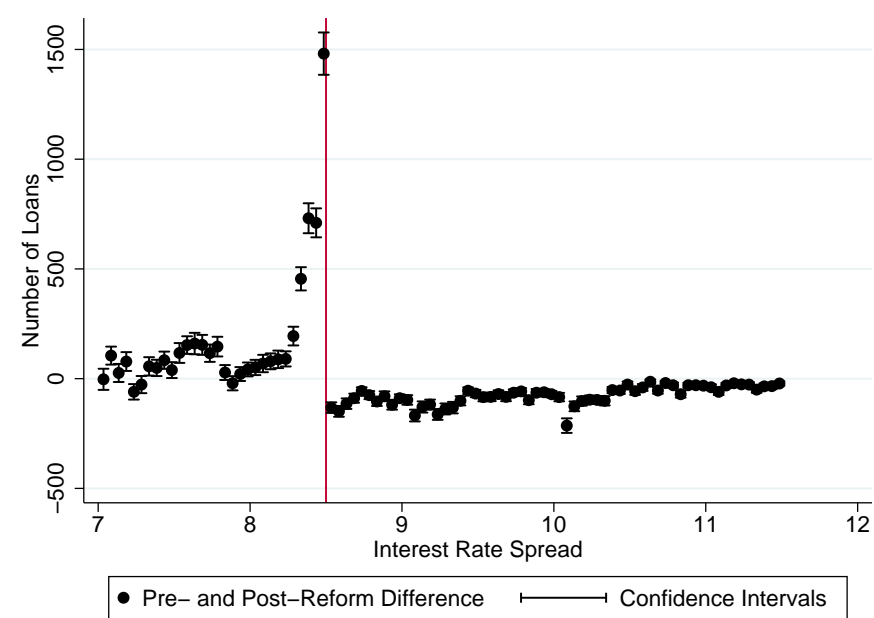

(b) $2015-2013$

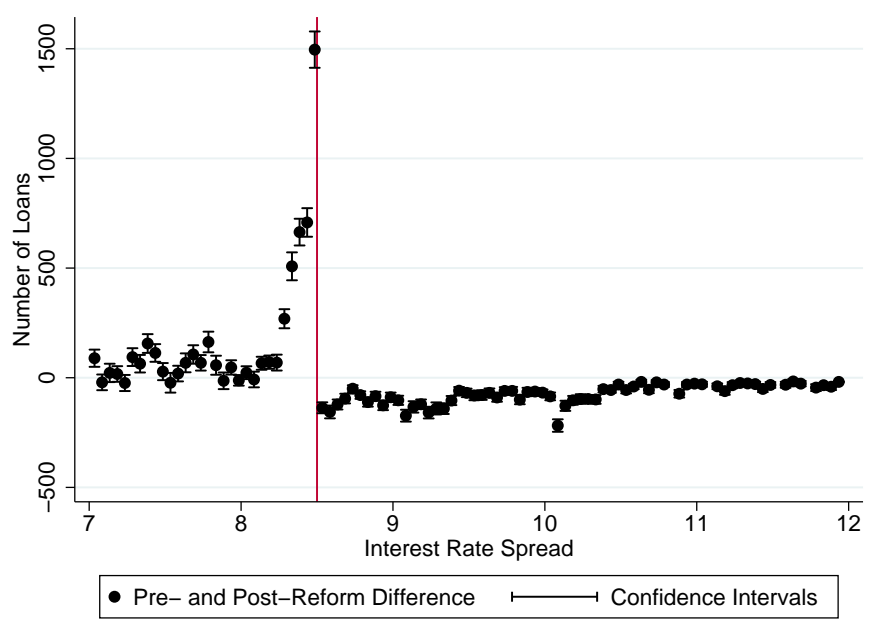

(d) $2017-2013$

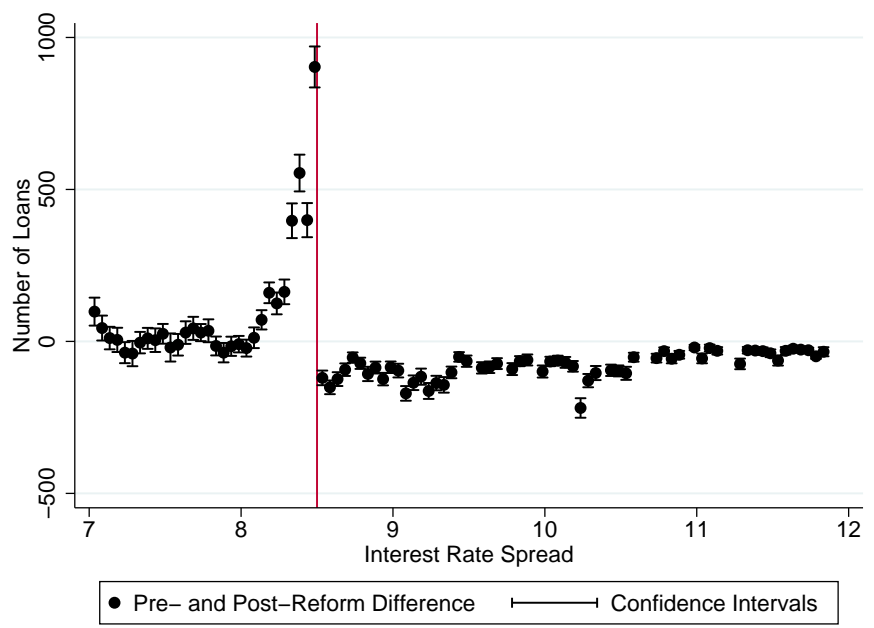

Notes: These figures plot the difference in the pre- and post-reform distributions around the 8.5\% HOEPA cutoff, comparing 2013 to 2014 (Figure 3a), 2015 (Figure 3b), 2016 (Figure 3c) and 2017 (Figure 3d). The red vertical line represents the 8.5\% cutoff and the bin size is 0.05 . The bars represent the $95 \%$ confidence intervals. 
Figure 4: Number of Loans Over Time

(a) Number of Loans: Loan Amounts $\geq \$ 50,000$

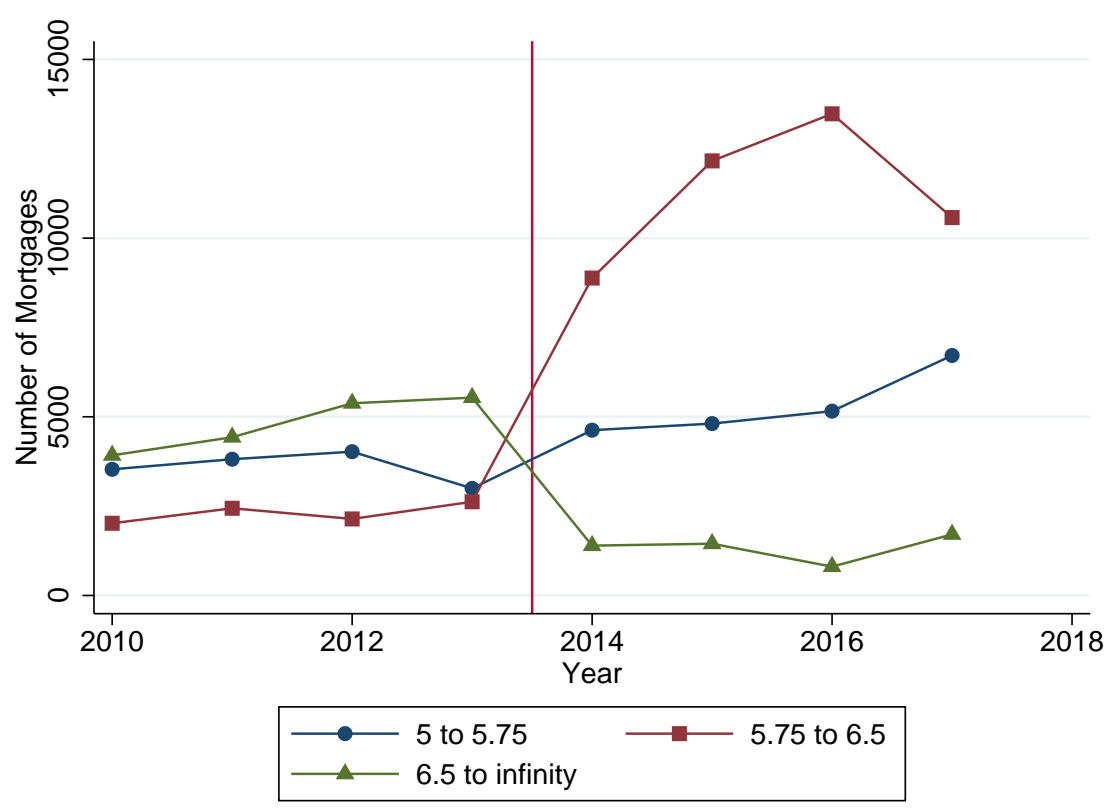

(b) Number of Loans: Loan Amounts $<\$ 50,000$

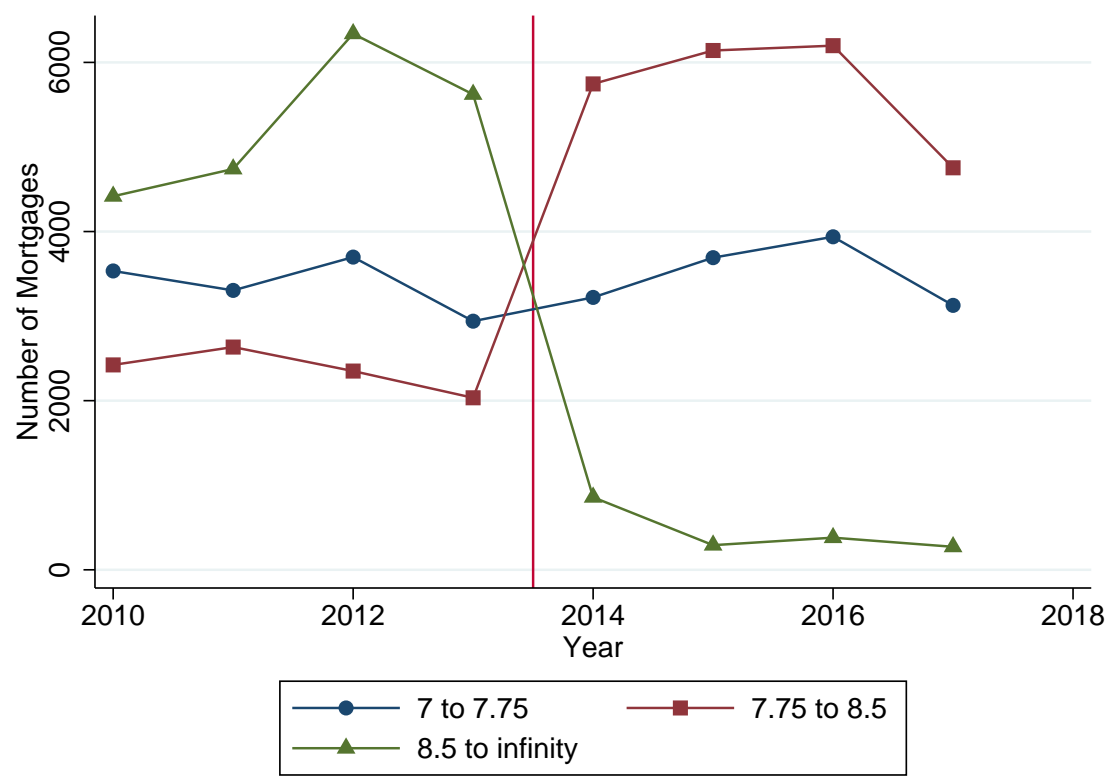

Notes: These figures plot the number of loans approved over time in the neighborhood of the two HOEPA thresholds: Figure $4 \mathrm{a}$ plots it for the $6.5 \%$ threshold and Figure $4 \mathrm{~b}$ for the $8.5 \%$. 
Figure 5: Average Interest Rate by Year

(a) Interest Rate Spread: Loans $\geq \$ 50,000$

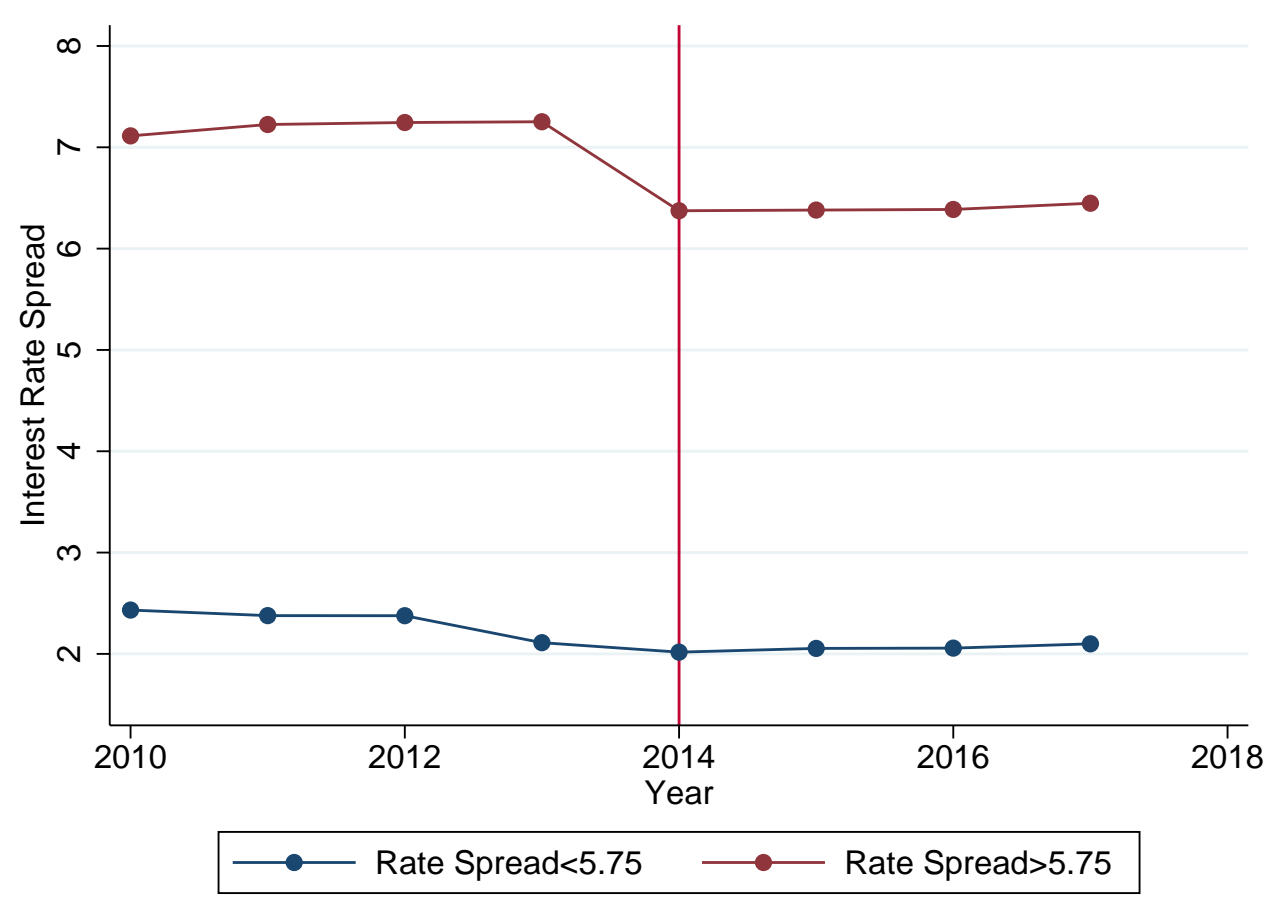

(b) Interest Rate Spread: Loans $<\$ 50,000$

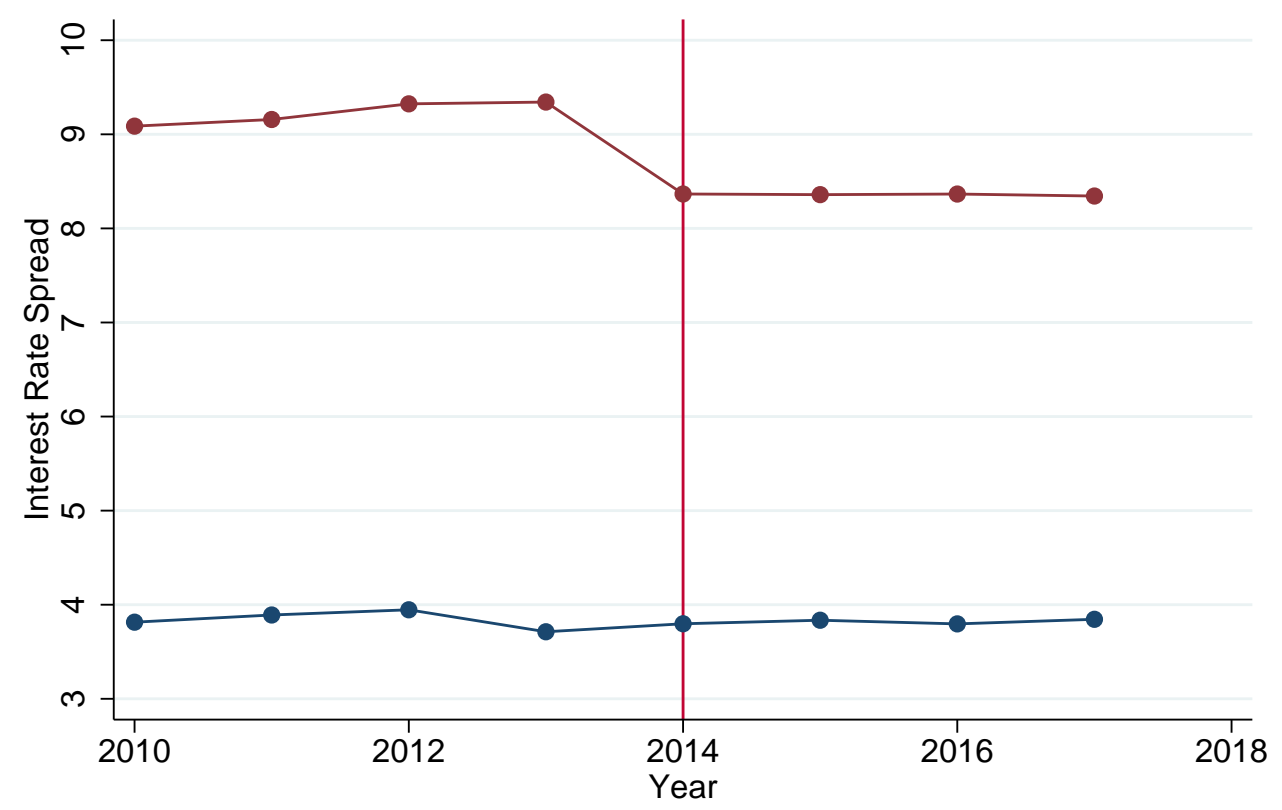

$\longrightarrow$ Rate Spread $<7.75 \quad \longrightarrow$ Rate Spread $>7.75$

Notes: These figures plot the average interest rates over time for loans just below and above the threshold compared to all other loans. Note that we do not use a lower bound on interest rates for the control group because it would otherwise artificially bound the series (as shown in Appendix Figure A.5). 
Figure 6: Distribution of the Percentage of HOEPA Loans in a Given Lender's Portfolio of Loans

(a) All Years

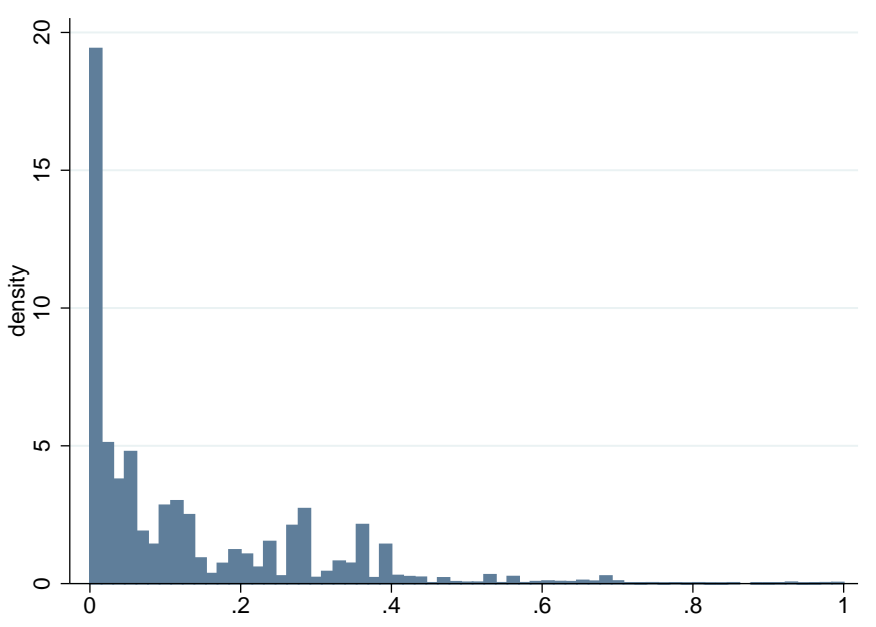

(b) Pre-Reform Years

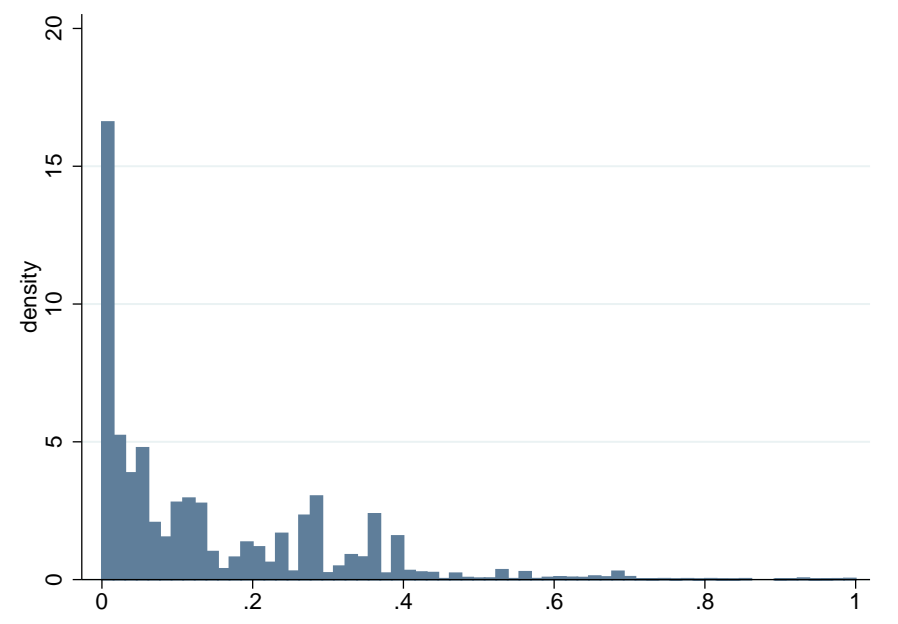

(c) Post-Reform Years

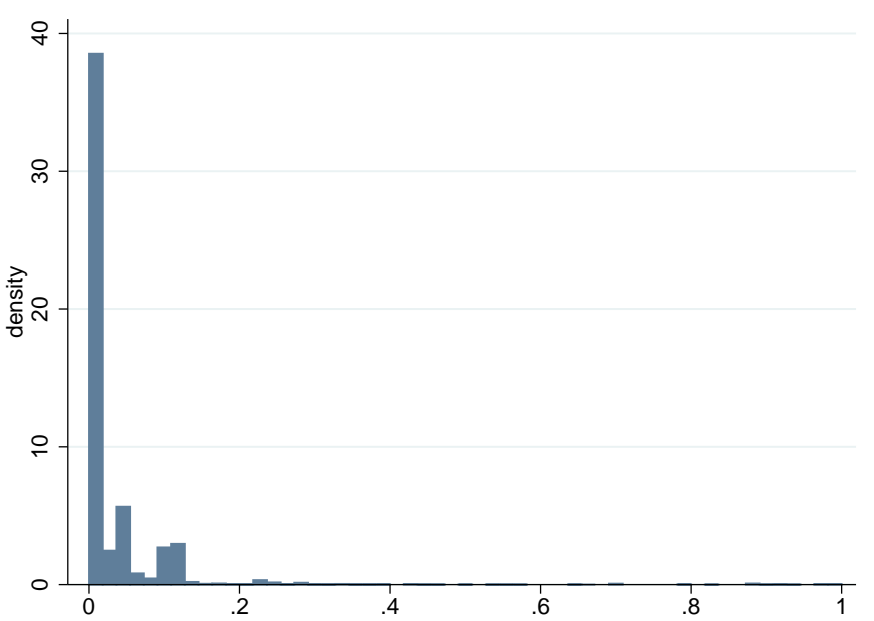

Notes: These figures plot the distribution of the percentage of HOEPA loans in a given lender's total portfolio of loans. Figure 6a plots it for all years, $6 \mathrm{~b}$ for pre-reform years, and $6 \mathrm{c}$ for post-reform years. These distributions do not include lenders who do not issue any HOEPA loans. (See Appendix Figure A.7 for the distributions that include these lenders). 
Figure 7: Entry and Exit

(a) Number of High-Interest Lenders Around the 6.5\% Cutoff

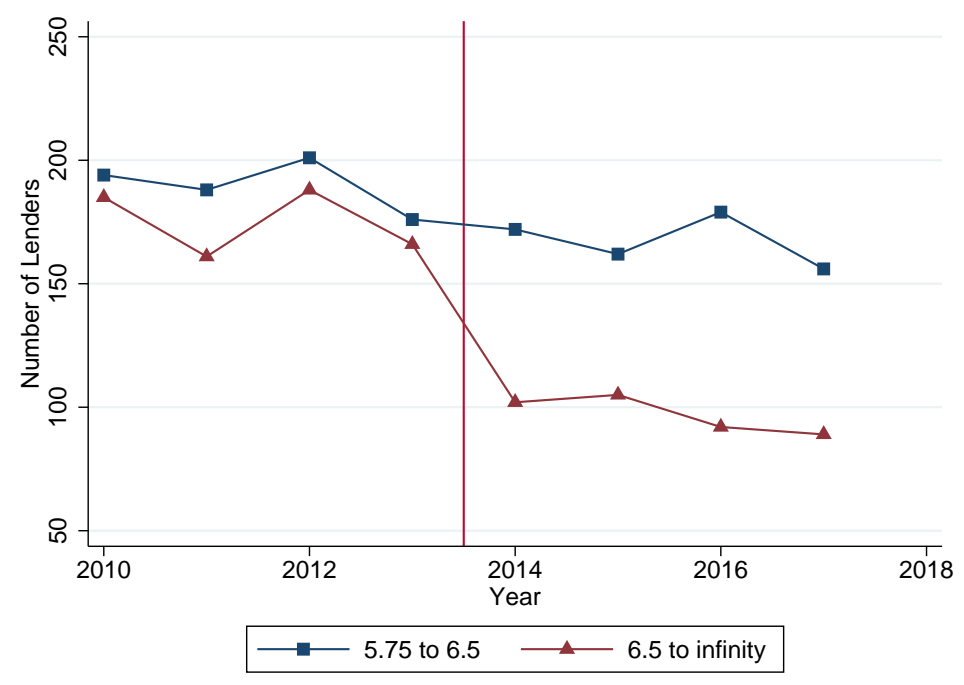

(b) Number of High-Interest Lenders Around the 8.5\% Cutoff

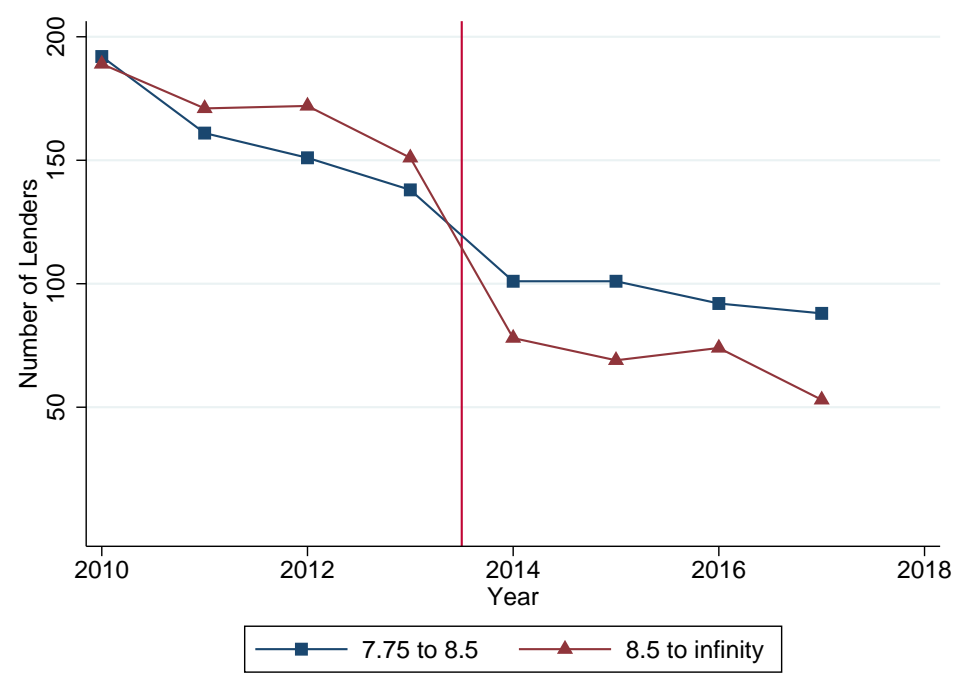

Notes: These figures plot the number of high-interest lenders over time. Figures $7 \mathrm{a}$ and $7 \mathrm{~b}$ compare the number of lenders who issue loans above the HOEPA cutoff compared to just below the cutoff. 
Table 1: Summary Statistics

\begin{tabular}{lccc} 
& Low-Interest Loans & High-Interest Loans & Difference \\
\hline Income $(\$ 1,000)$ & 113.9 & 60.6 & 53.3 \\
& $(0.023)$ & $(0.14)$ & $(0.32)$ \\
$\mathrm{N}$ & $50,748,360$ & 261,306 & \\
\hline Proportion African American & $4.65 \%$ & $10.3 \%$ & $-5.65 \%$ \\
& $(0.0000284)$ & $(0.0005892)$ & $(0.0004103)$ \\
$\mathrm{N}$ & $55,005,012$ & 266,201 & \\
\hline Proportion Hispanic & $7.25 \%$ & $11.90 \%$ & $-4.65 \%$ \\
$\mathrm{~N}$ & $(0.000035)$ & $(0.0006275)$ & $(0.0005044)$ \\
\hline Proportion Female & 55005012 & 266,201 & \\
& $25.83 \%$ & $34.01 \%$ & $-8.18 \%$ \\
$\mathrm{~N}$ & $(0.000059)$ & $(0.0009182)$ & $(0.0008508)$ \\
\hline
\end{tabular}

Notes: This table shows summary statistics for low- versus high-interest borrowers. Standard errors are in parentheses.

Table 2: Effect of the Reform on Interest Rates and Loan Amounts

\begin{tabular}{lcc|cc}
\hline \hline & \multicolumn{2}{c}{ Loan Amount $\geq \$ 50,000$} & \multicolumn{2}{c}{ Loan Amount $<\$ 50,000$} \\
& Rate Spread & Loan Amount & Rate Spread & Loan Amount \\
\hline After $\times$ Treat & -0.60 & -7.71 & -0.93 & 1.32 \\
& $(0.15)$ & $(8.54)$ & $(0.23)$ & $(0.75)$ \\
Treat & 4.94 & -71.0 & 5.49 & -1.94 \\
& $(0.091)$ & $(5.19)$ & $(0.14)$ & $(1.72)$ \\
After & & & & \\
& -0.23 & 22.3 & -0.026 & 1.82 \\
& $(0.033)$ & $(2.91)$ & $(0.13)$ & $(0.42)$ \\
Constant & 2.29 & 151.5 & 3.84 & 29.4 \\
& $(0.045)$ & $(2.41)$ & $(0.13)$ & $(0.37)$ \\
\hline $\mathrm{R}^{2}$ & 0.52 & 0.0064 & 0.45 & 0.0077 \\
Observations & $2,473,899$ & $2,473,721$ & 595,451 & 595,451 \\
\hline \hline
\end{tabular}

Notes: This table reports the results of estimation equation (2). Standard errors are clustered at the lender level and are in parentheses. 


\section{A APPENDIX: FOR ONLINE PUBLICATION}


Figure A.1: Pre-Reform Distributions for Loan Amounts $\geq \$ 50,000$

(a) 2010

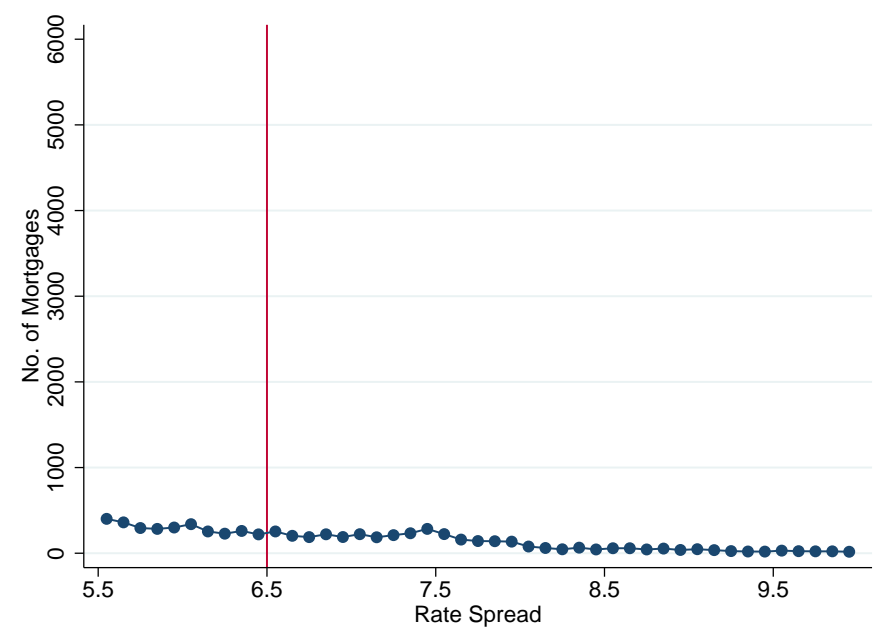

(c) 2012

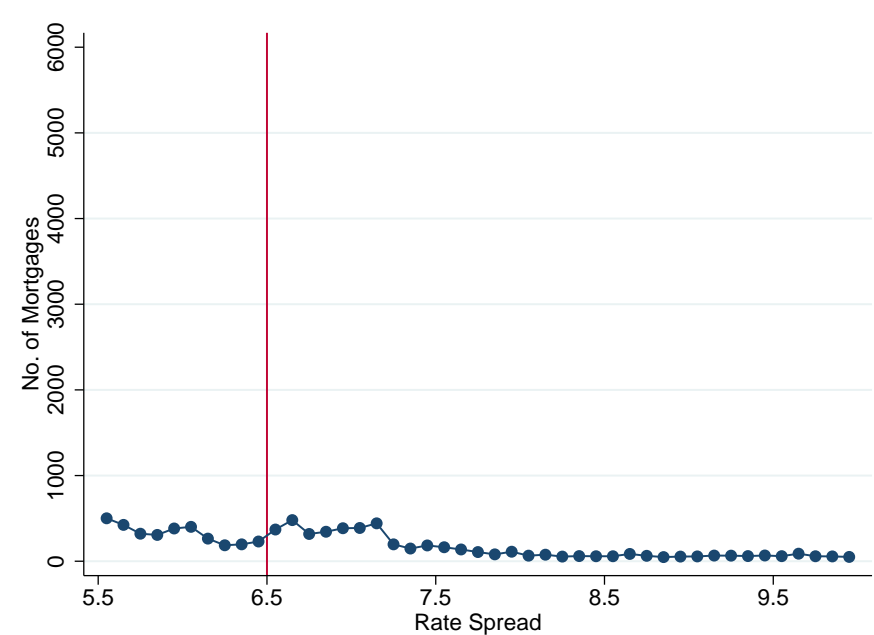

(b) 2011

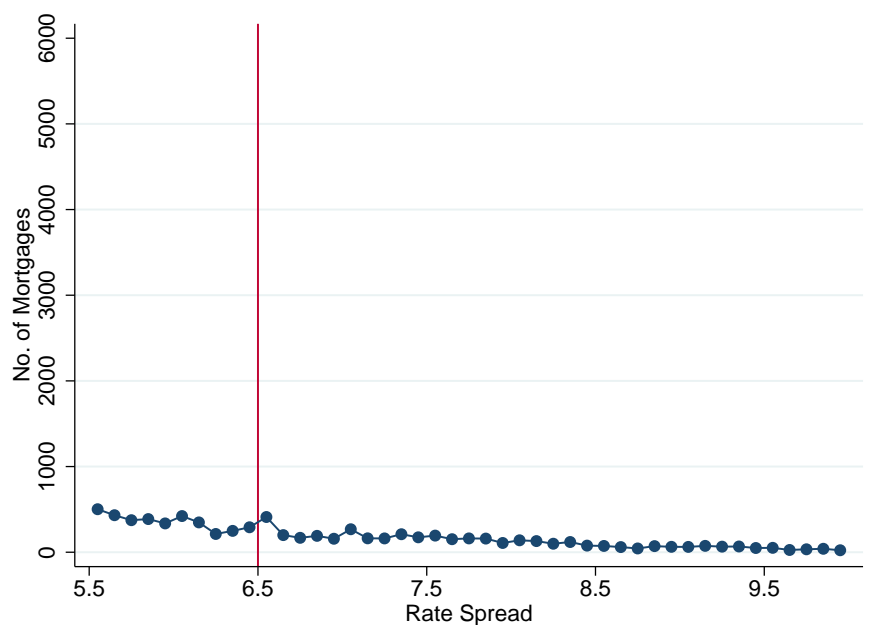

(d) 2013

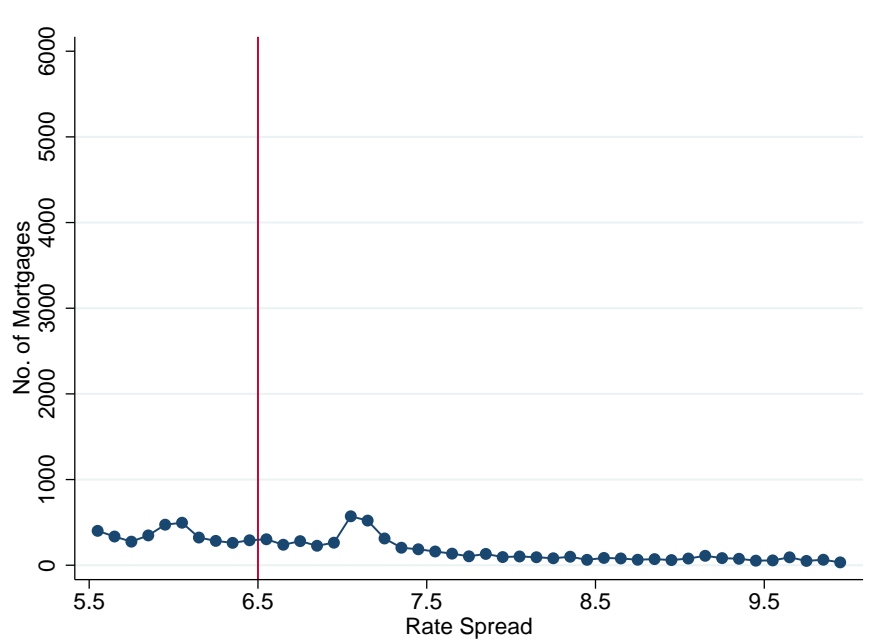

Notes: These figures plot the distribution of loans with interest rate spreads $\geq 5.5 \%$ for loan amounts $\geq \$ 50,000$ in 2010,2011 , 2012, and 2013. The red vertical line marks the 6.5\% HOEPA cutoff introduced in 2014. The bin size used is 0.1 . 
Figure A.2: Post-Reform Distributions for Loan Amounts $\geq \$ 50,000$

(a) 2014

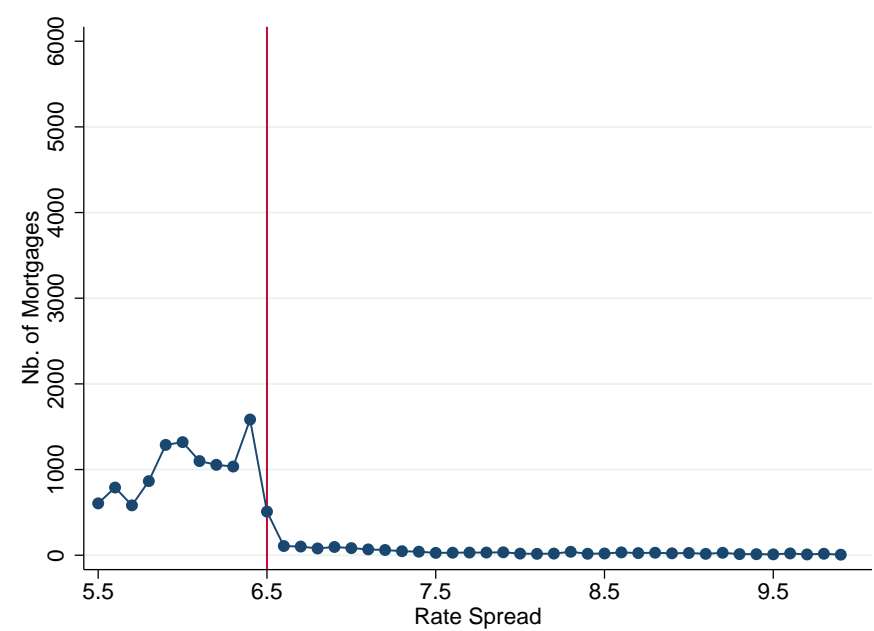

(c) 2016

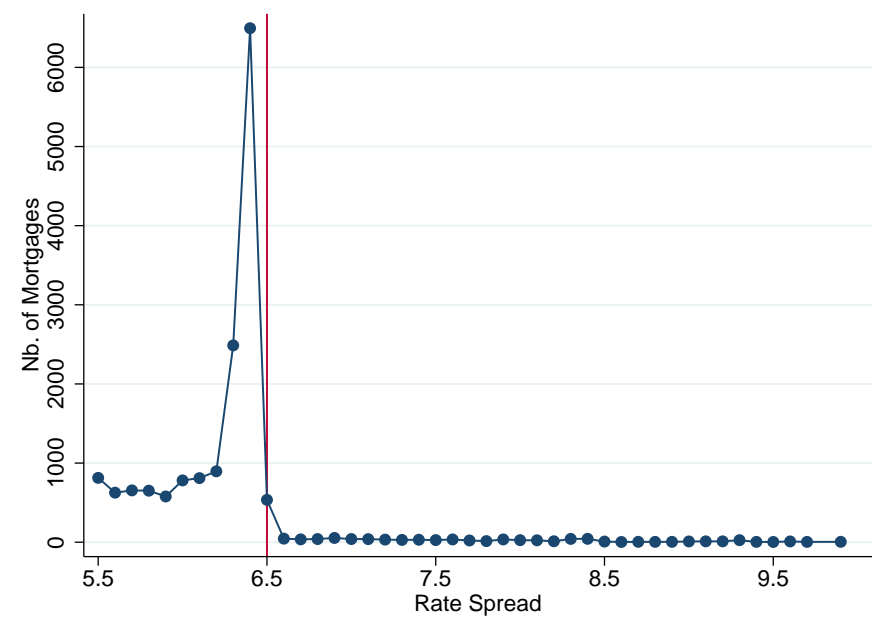

(b) 2015

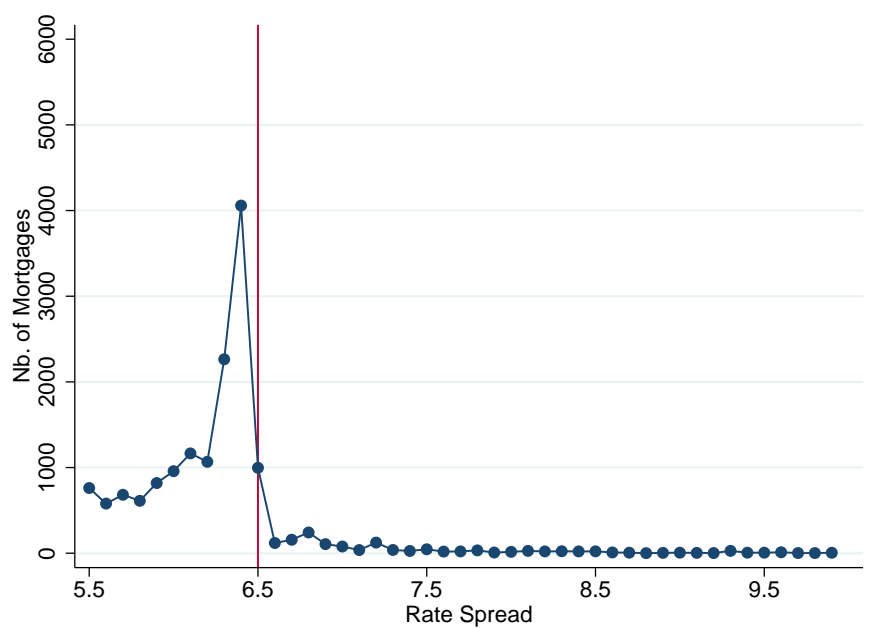

(d) 2017

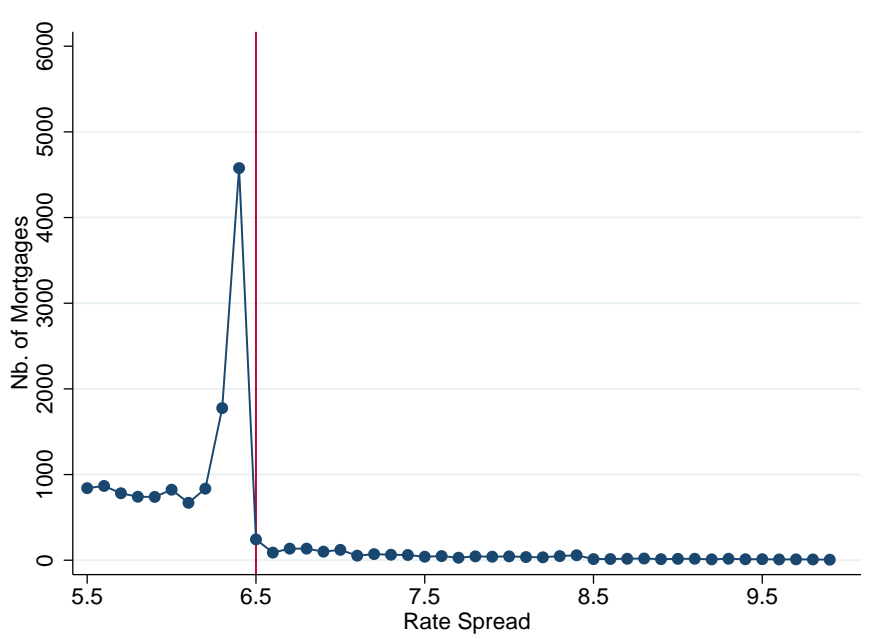

Notes: These figures plot the distribution of loans with interest rate spreads $\geq 5.5 \%$ for loan amounts $\geq \$ 50,000$ in 2014,2015 , 2016, and 2017. The red vertical line marks the 6.5\% HOEPA cutoff introduced in 2014. The bin size used is 0.1 . 
Figure A.3: Pre-Reform Distributions for Loan Amounts $<\$ 50,000$

(a) 2010

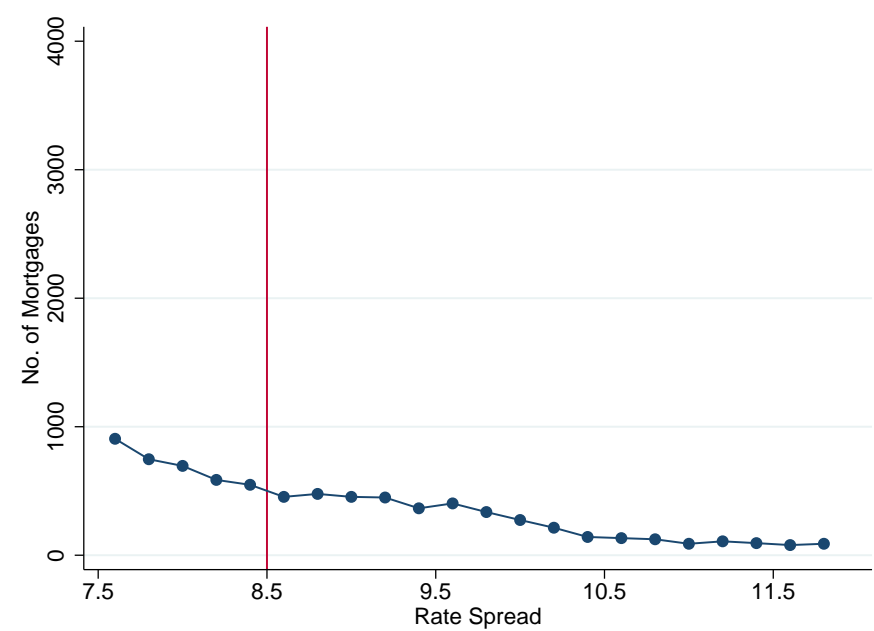

(c) 2012

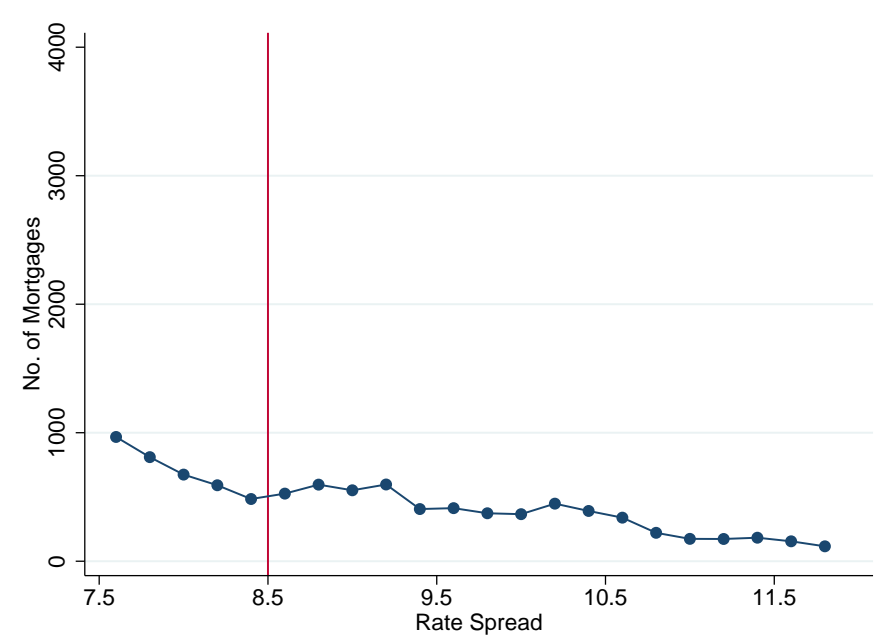

(b) 2011

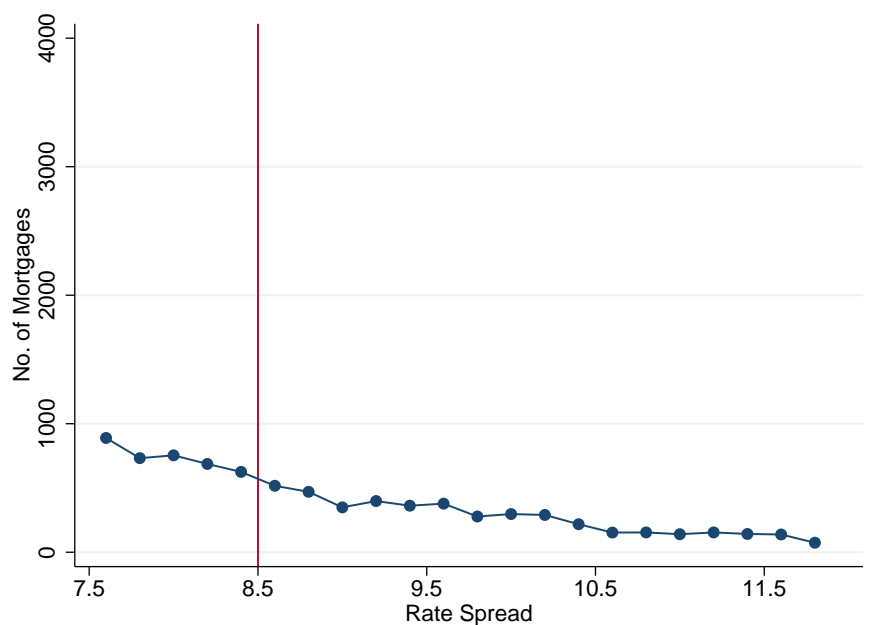

(d) 2013

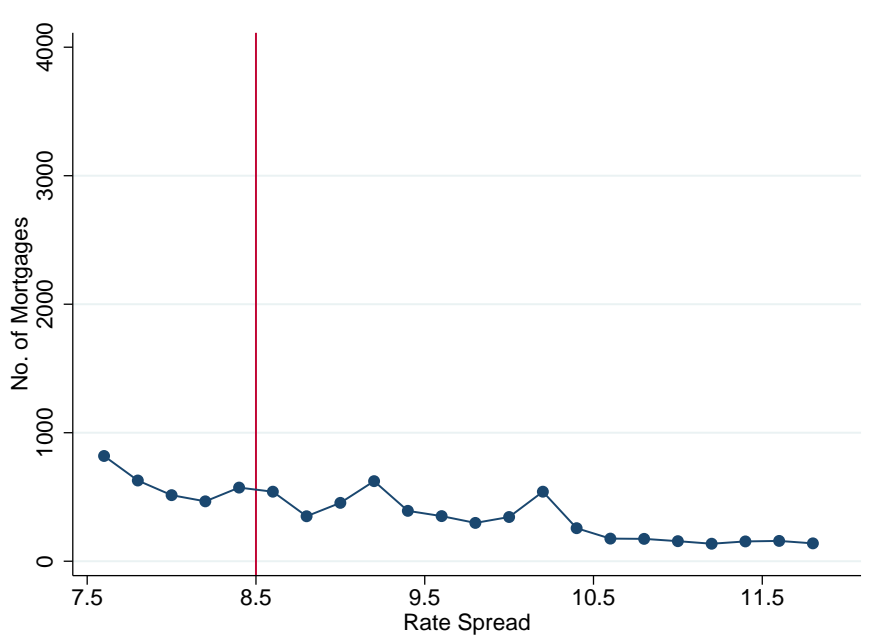

Notes: These figures plot the distribution of loans with interest rate spreads $\geq 7.5 \%$ for loan amounts $<\$ 50,000$ in 2010,2011 , 2012, and 2013. The red vertical line marks the 8.5\% HOEPA cutoff introduced in 2014. The bin size used is 0.2. 
Figure A.4: Post-Reform Distributions for Loan Amounts $<\$ 50,000$

(a) 2014

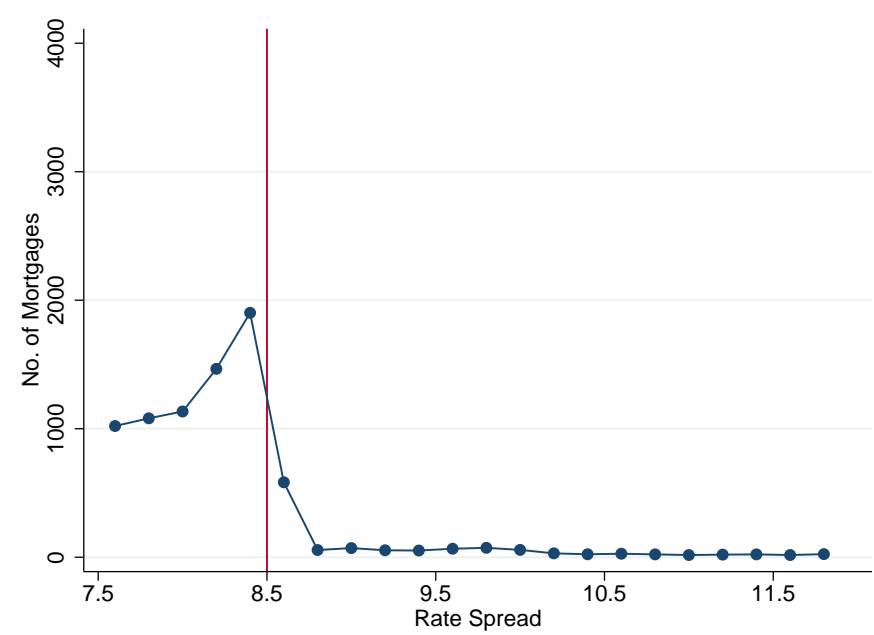

(c) 2016

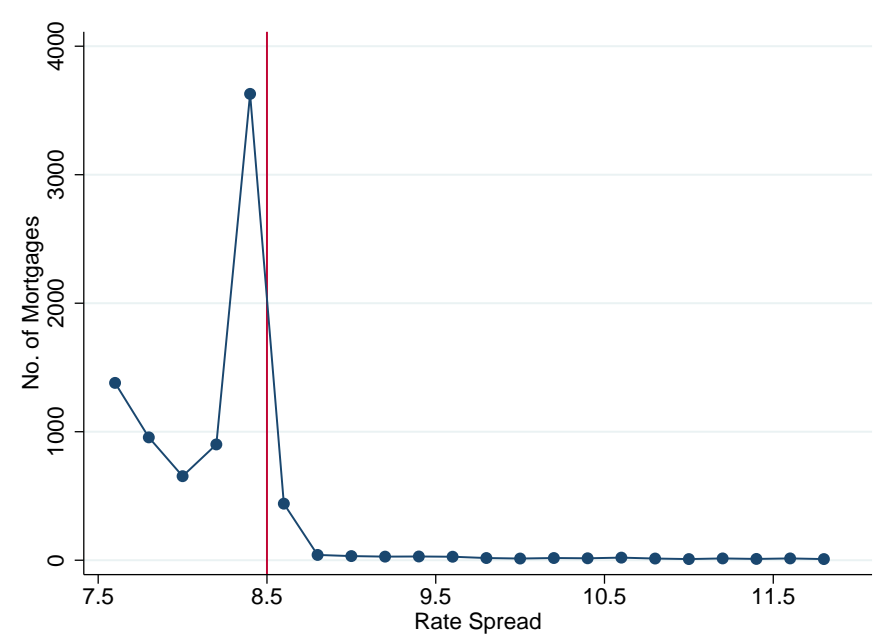

(b) 2015

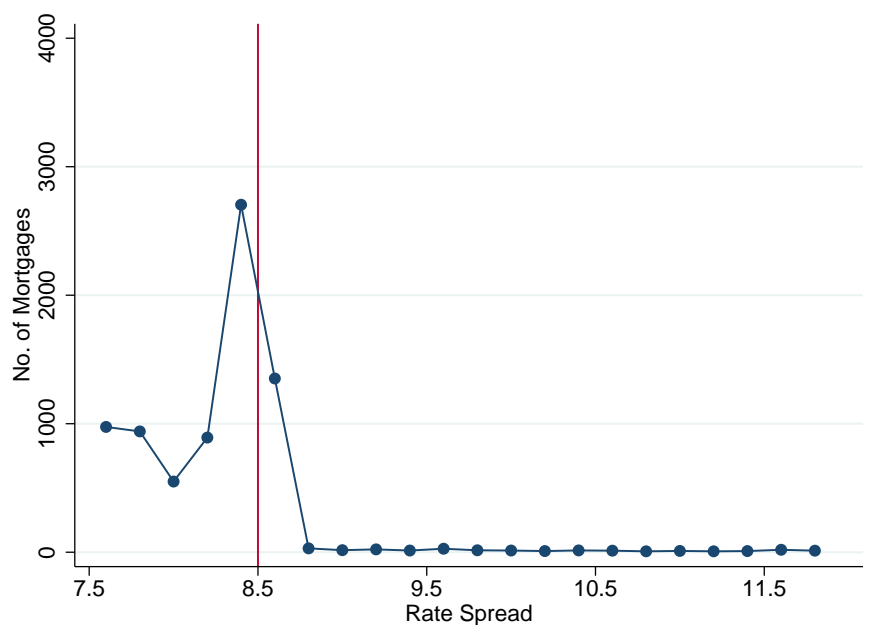

(d) 2017

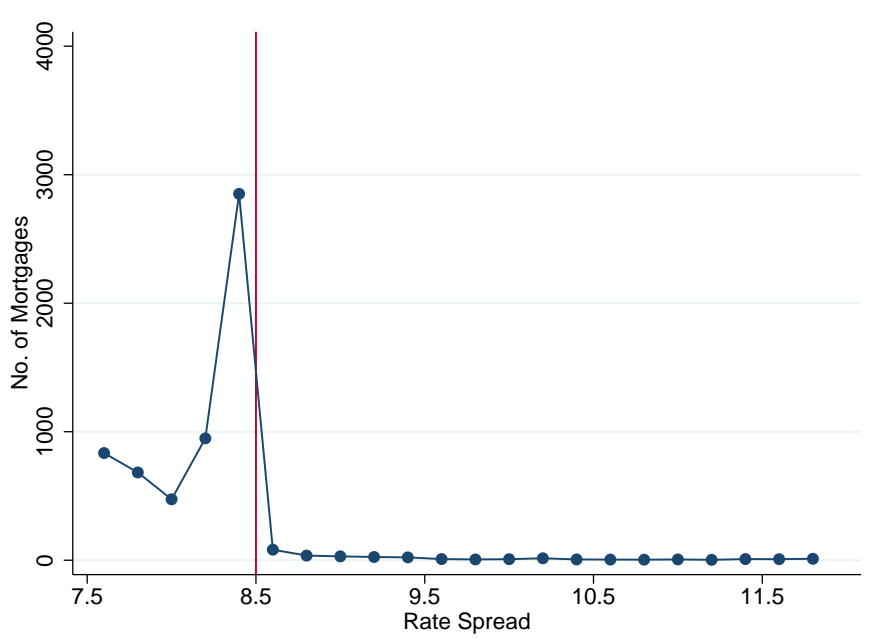

Notes: These figures plot the distribution of loans with interest rate spreads $\geq 7.5 \%$ for loan amounts $<\$ 50,000$ in 2014,2015 , 2016, and 2017. The red vertical line marks the 8.5\% HOEPA cutoff introduced in 2014. The bin size used is 0.2 . 
Figure A.5: Average Interest Rate by Year with Lower Bound on Control Group

(a) interest-rate spread: Loans $\geq \$ 50,000$

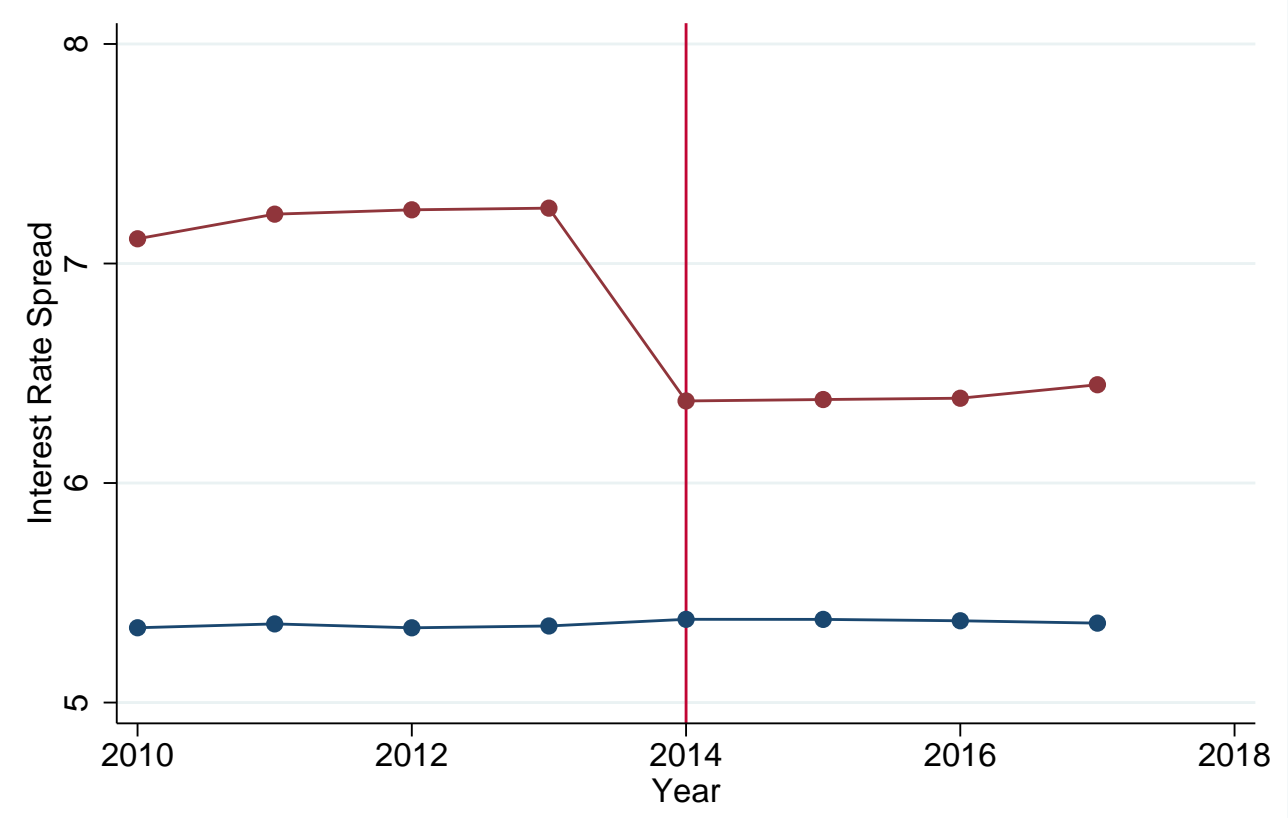

Rate Spread 5 to $5.75 \longrightarrow$ Rate Spread $>5.75$

(b) interest-rate spread: Loans $<\$ 50,000$

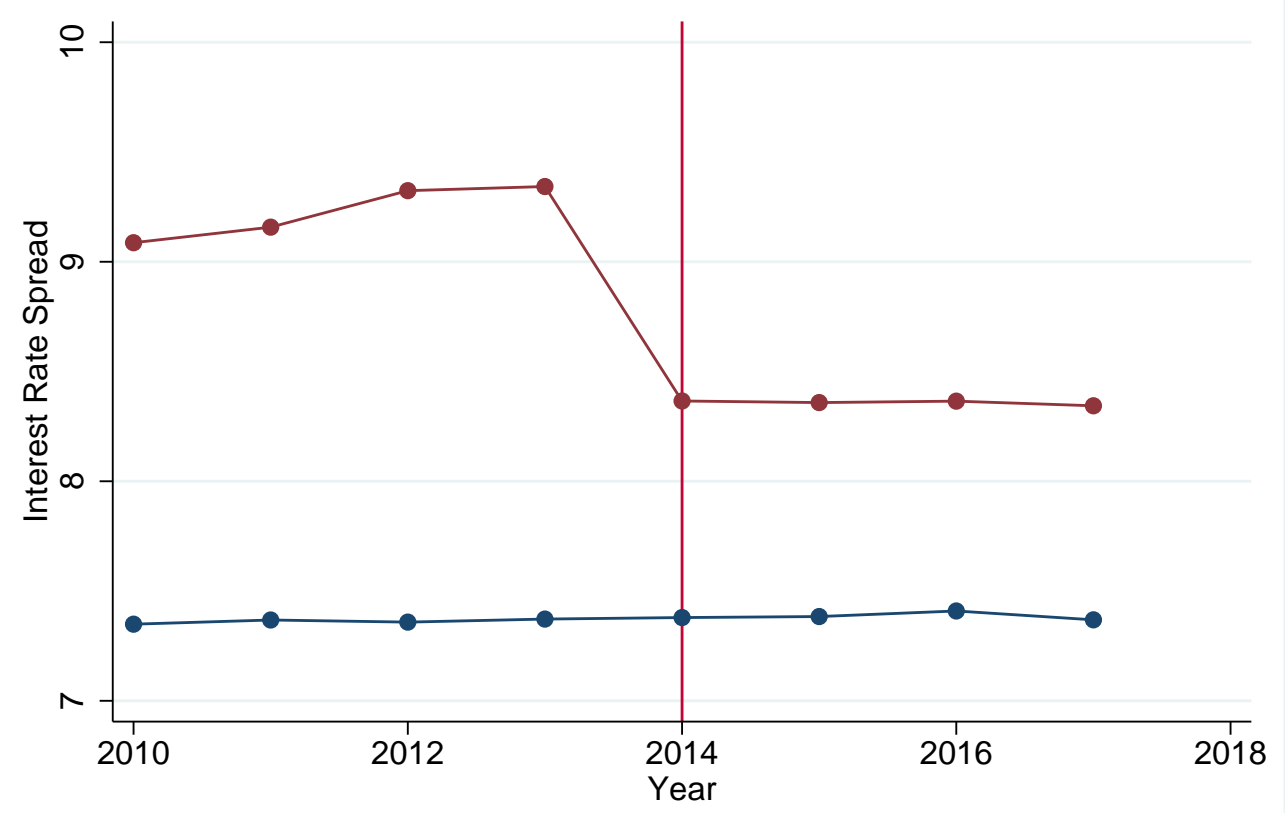

$\longrightarrow$ Rate Spread 7 to $7.75 \longrightarrow$ Rate Spread $>7.75$

Notes: These figures plot the average interest rates over time for loans just below and above the threshold compared to all other loans. Note that the control group is defined as loans with interest-rate spreads ranging from 5 to $5.75 \%$ for the $6.5 \%$ HOEPA threshold and 7 to $7.75 \%$ for the $8.5 \%$ threshold. 
Figure A.6: Total Credit

(a) Total Credit: Loans $\geq \$ 50,000$

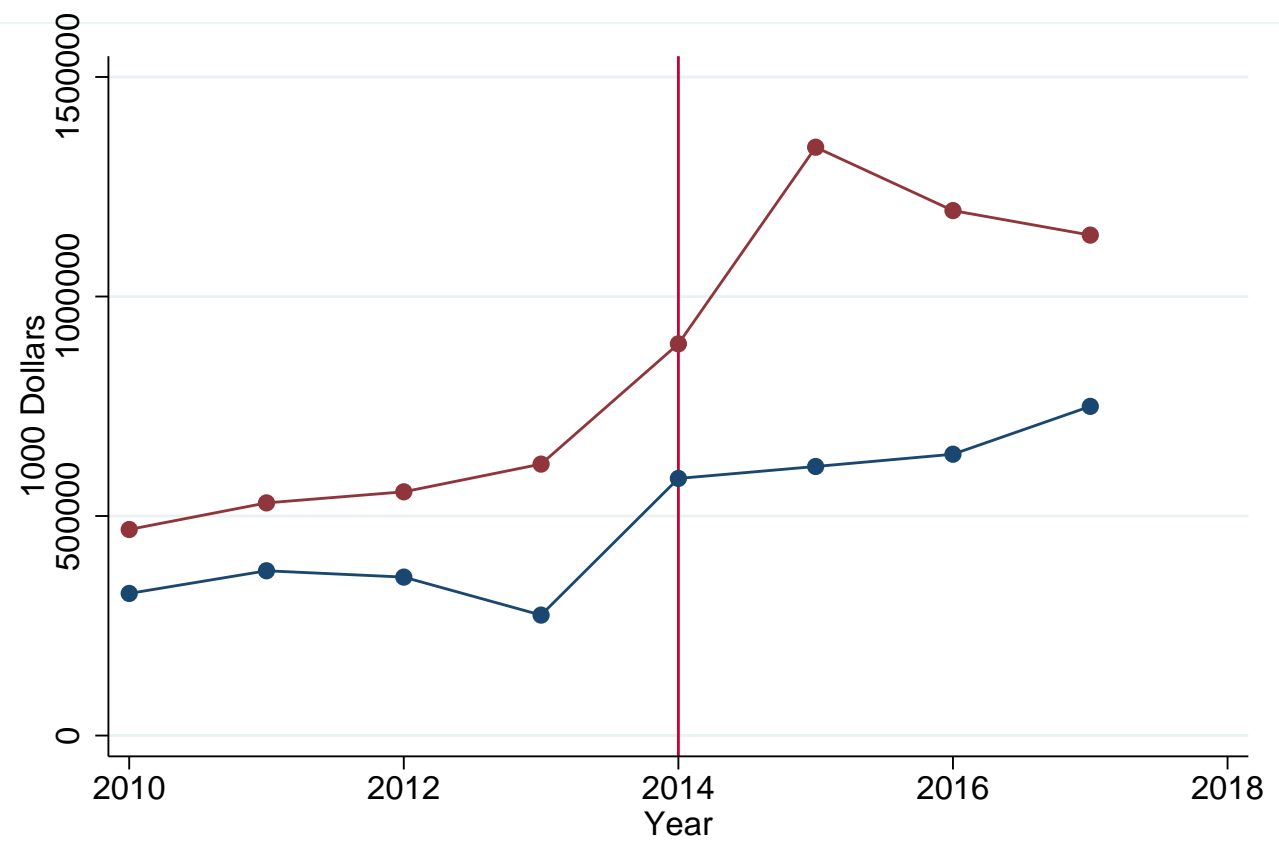

\section{$\longrightarrow$ Rate Spread 5 to $5.75 \% \quad \longrightarrow$ Rate Spread Above $5.75 \%$}

(b) Total Credit: Loans $<\$ 50,000$

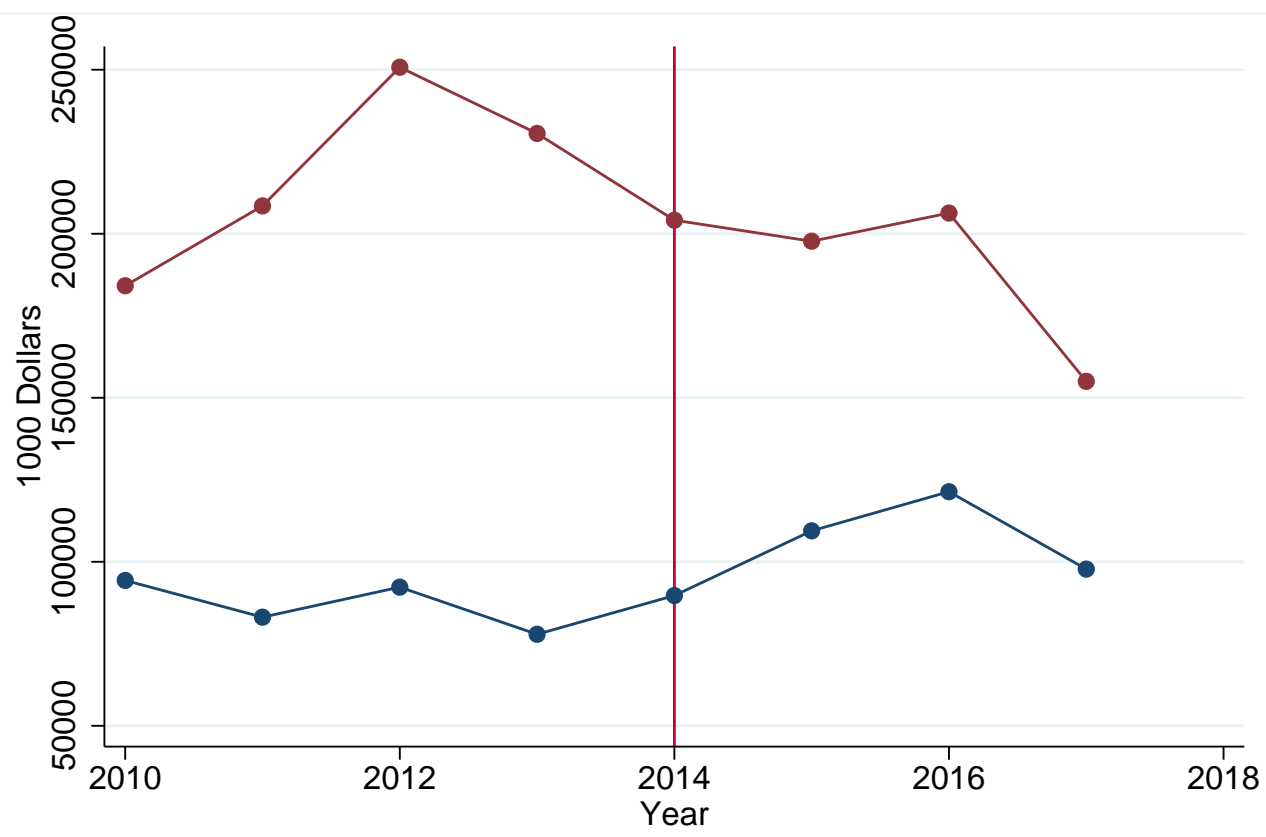

$\longrightarrow$ Rate Spread 7 to $7.75 \% \quad \longrightarrow$ Rate Spread Above $7.75 \%$

Notes: These figures plot the total credit approved for loans in the manipulated area close to the HOEPA cutoff compared to those that are just below this area. 
Figure A.7: Distribution of the Percentage of HOEPA Loans in a Given Lender's Portfolio of Loans

(a) All Years

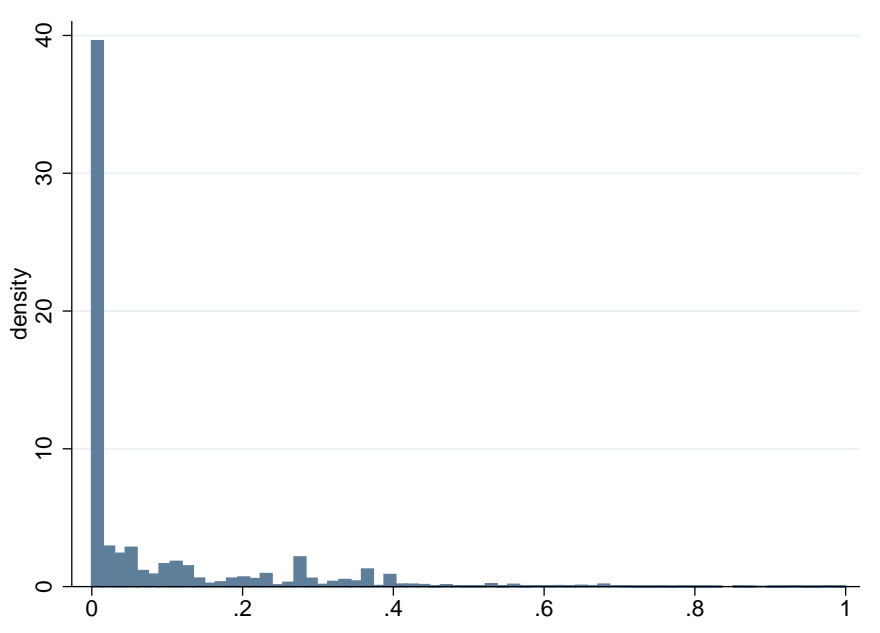

(b) Pre-Reform Years

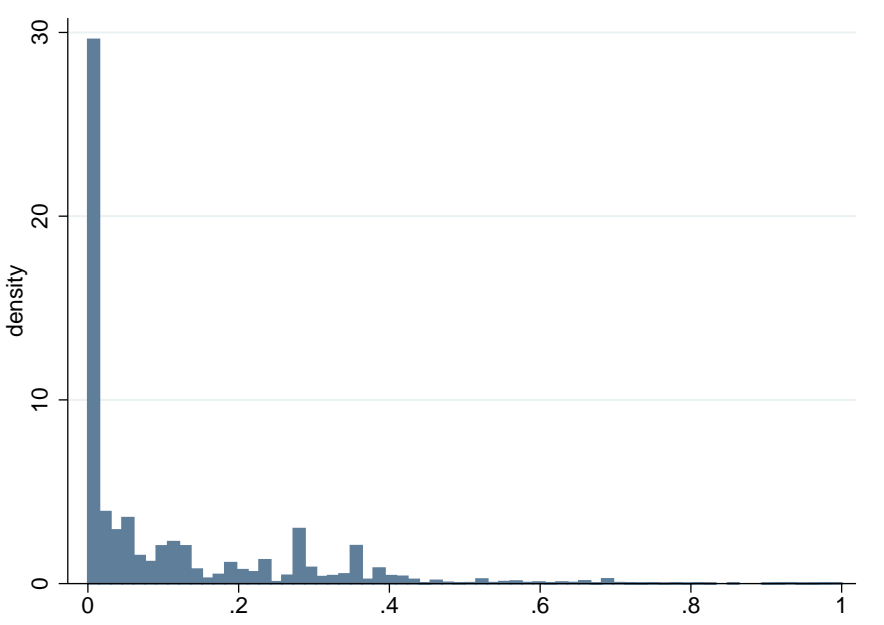

(c) Post-Reform Years

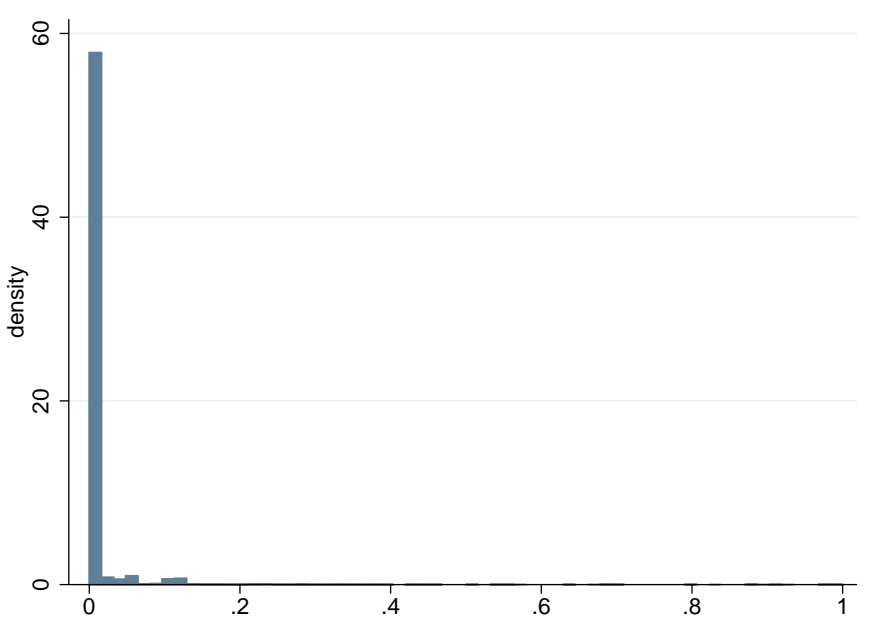

Notes: These figures plot the distribution of the percentage of HOEPA loans in a given lenders total portfolio of loans. Figure A.7a plots it for all years, A.7b for pre-reform years and A.7c for post-reform years. These distributions include lenders who do not issue any HOEPA loans. 